FIU Law Review

Fall 2014

\title{
Don't Be a Drag, Just Be a Queen-How Drag Queens Protect their Intellectual Property without Law
}

\author{
Eden Sarid \\ University of Toronto
}

Follow this and additional works at: https://ecollections.law.fiu.edu/lawreview

Part of the Other Law Commons

Online ISSN: 2643-7759

\section{Recommended Citation}

Eden Sarid, Don't Be a Drag, Just Be a Queen-How Drag Queens Protect their Intellectual Property without Law, 10 FIU L. Rev. 133 (2014).

DOI: https://dx.doi.org/10.25148/lawrev.10.1.11

This Article is brought to you for free and open access by eCollections. It has been accepted for inclusion in FIU Law Review by an authorized editor of eCollections. For more information, please contact lisdavis@fiu.edu. 


\title{
Don't Be a Drag, Just Be a Queen-How Drag Queens Protect their Intellectual Property without Law
}

\author{
Eden Sarid
}

\section{INTRODUCTION}

As the lights dim, Dame Shirley Bassey's Get the Party Started starts playing. From behind the curtains, the Dame's (almost perfect, though a bit extravagant) lookalike appears and indeed gets the party started. By the end of the evening the performer, a drag queen, changed at least five wigs and eight dresses, changed makeup several times, and performed eight different choreographed routines. An enormous amount of time and intellectual labor was invested in finding the best songs for the show, devising the best dance moves and the perfect lip-sync, matching the perfect dress and wig, and fitting the exact make-up. Inevitably, the fruit of this intellectual labor, the drag show, is at risk of being appropriated as a fellow queen may easily copy the moves and costumes of the original performer, and put on a rival show of her own. One might assume that if such a scenario were to happen, litigation on intellectual property infringement grounds would soon follow. However, drag queens do not revert to copyright law or any other formal legal course of action. The reason is, apparently, because copyright law fails to offer drag queens an effective way to protect their intellectual creations, but a different ordering system does.

Common intellectual property ("IP") wisdom would have us think that in the absence of effective legal remedy against this kind of copying or appropriation the creative domain of drag performances ("the drag domain") is destined to become a creativity wasteland, since creators would not be able to recoup adequate rewards for their creation and, thus, refrain from investing time and effort in the first place. ${ }^{1}$ Nevertheless, even

* SJD Candidate, University of Toronto. The author wishes to thank Haim Abraham; Omri BenZvi; Michael Birnhack; Manuel Gomez; Ariel Katz; Aaron Perzanowski; Barak Richman; the participants of the Conference for Junior Researchers, Stanford Program in Law and Society, Stanford Law School; and the participants of the Layers of Law and Social Order Symposium, Florida International University College of Law, for helpful comments and conversations. I also wish to thank the editors of the FIU Law Review for their helpful suggestions. Finally, I extend my deepest gratitude to the wonderful drag performers and services providers who devoted their time to talk to me and to educate me about the fascinating world of drag. My obligation to anonymity prevents me from thanking each of them by name, however it is them who made this study possible.

1 The literature on the subject is vast. See, e.g., William W. Fisher, Theories of Intellectual Property, in New Essays in the Legal \& Political Theory of Property (Stephen R. Munzer ed., 2001) (providing an overview of the different approaches to IP theory); see also PETER MENELL, InTELlectual Property General TheORIES, ENCyClopedia of LAW \& ECONOMics (Bouckaert, 
without formal legal regulation, the Israeli drag domain is thriving with more shows and more queens than ever before. This article aims to figure out how this happens and what the lessons this phenomenon might hold for IP theory and policy.

The drag domain is not alone. Recent studies examined other domains of intellectual creativity that flourish without (or with only a low level of) IP legal protection, what we might call extra-legal domains. ${ }^{2}$ Scholars explored fashion, stand-up comedy, graffiti, high cuisine, magic performances, tattoos, typefaces, and even roller derby pseudonyms, just to name a few. ${ }^{3}$ The primary goal of the scholarly literature on extra-legal domains was to explain how the domains flourish despite lack of (or minor) legal regulation. The answer that has surfaced thus far suggests that the extra-legal domains substitute for the legal regulation by reverting to social norms, which are usually practiced amongst the cadre of creators or, in a few cases, a fashion cycle. Here, I shall call them intra-social norms. ${ }^{4}$

Based on a series of extensive interviews with Israeli drag queens, as well as a few interviews with owners of venues in which the drag performances take place, this study suggests that the drag domain, like most other extra-legal domains, extensively relies on an intra-social norm system

Boudewijn \& De Geest, Gerrit, eds., 2000); Rochelle Cooper Dreyfuss, Does IP Need IP? Accommodating Intellectual Production outside the Intellectual Property Paradigm, 31 CARDOzo L. REV. 1437 (2010) (analyzing the meaning of extra-legal domains to fundamental IP theories); William M. Landes \& Richard A. Posner, An Economic Analysis of Copyright Law, 18 J. LEG. STUD. 325 (1989) (outlining the economic theory of copyright law).

2 Christopher Sprigman and Kal Raustiala coined the term IP's Negative Spaces, which they defined as areas where creation and innovation thrive without significant formal intellectual property protection. See Christopher Sprigman \& Kal Raustiala, The Piracy Paradox: Innovation and Intellectual Property in Fashion Design, 92 VA. L. REV. 1687, 1762 (2006).

3 Sprigman \& Raustiala, supra note 2; Christopher Sprigman \& Dotan Oliar, There's No Free Laugh (Anymore): The Emergence of Intellectual Property Norms and the Transformation of Stand-Up Comedy, 94 VA. L. REV 1787 (2008); Al Roundtree, Graffiti Artists “Get Up" In Intellectual Property's Negative Space, 31 CARDOZO ARTS \& ENT. L.J. 959 (2013); Emmanuelle Fauchart \& Eric Von Hippel, Norms-Based Intellectual Property Systems: The Case of French Chefs, 19 ORG. SCIENCE 187 (2008); Jacob Loshin, Secrets Revealed: How Magicians Protect Intellectual Property without Law, in LAW \& Magic: A Collection OF EsSAYs 123 (Christine A. Corcos ed., 2010); Aaron Perzanowski, Tattoos \& IP Norms, 98 MinN. L. Rev. 511 (2013); Blake Fry, Why Typefaces Proliferate Without Copyright Protection, 8 J. Telecomm. \& High TeCH. L. 425 (2010); Jacqueline D. Lipton, To (C) or Not to C)? Copyright and Innovation in the Digital Typeface Industry, 43 U.C. DAVIS L. REV. 143 (2009); David Fagundes, Talk Derby to Me: Intellectual Property Norms Governing Roller Derby Pseudonyms, 90 TEX. L. REv. 1093 (2012); see also F. Scott Kieff, Robert G. Kramer \& Robert M. Kunstadt, It's Your Turn, but It's My Move: Intellectual Property Protection for Sports "Moves", 25 SANTA Clara COMPUTER \& High TeCH. L.J. 765, 766 (2009); Katherine J. Strandburg, Legal But Unacceptable: Pallin v. Singer And Physician Patenting Norms, In Intellectual Property At The Edge: The Contested Contours OF IP (R. Dreyfuss \& J. Ginsburg, eds., forthcoming); Mark F. Schultz, Fear and Norms and Rock \& Roll: What Jambands Can Teach Us About Persuading People to Obey Copyright Law, 21 BERKELEY TECH. L.J. 651(2006).

4 While intra-social norms come in various modes, nearly all aim to supply the author with the right of exclusivity over her creation. 
to regulate its participants' intellectual creations. However, the drag domain contains yet another layer of social norms as an additional means of protection. Whereas the drag queens themselves practice the first layer of protection, namely the intra-social norms, it is other players in the drag scene who practice the second layer of social norms. These other players are the audience of the drag shows and related services providers, such as club owners and DJs, all of which have a part in the regulation of the drag domain. I shall call the second layer correlated-social norms. The intrasocial norms and the correlated social norms regulate the drag domain jointly and create the drag social norm system - a normative system based on social ordering that is aimed at protecting drag queens' intellectual creativity. It features a broad array of protected IP assets, appropriation prevention mechanisms, and a modular sanction scheme. As I will later discuss, the drag social norm system bears some relation to copyright law's principles such as norms against appropriation and norms regarding attribution. However, there are also some notable differences. For example, the drag norms provide protection for concepts and ideas and confer much shorter ownership terms.

In some ways the drag domain tells us a familiar story of an IP social norm-based community. However, as this article illustrates, two features particularly demonstrate its uniqueness vis-à-vis other extra-legal domains of IP, and its ability to extend and inform the discourse regarding IP law and social norms. First, the drag domain includes a broader range of protected IP assets compared to other studied extra-legal domains. These IP assets enjoy a modular protection scheme in which more important ownership assets enjoy a more robust protection. Additionally, unlike other extra-legal domains which present no (or very few) exceptions and limitations to ownership, the drag domain presents several such limitations and exceptions. This suggests that IP norm systems can be broad in scope and still include exceptions and limitations to ownership, a feature that was perhaps somewhat questionable given its rarity in other studies of extralegal domains. Second, the drag domain is unique in the sense that most of its anti-appropriation norms are crafted to prevent appropriation ex-ante rather than punish appropriators ex-post. In particular, the drag domain boasts a rich public domain which is fostered and protected by all the members of the creative community. This proposes an innovative way of thinking about IP regulation and about enforcement.

The drag domain, I suggest, also teaches us a valuable lesson regarding the way law possibly affects creativity. It teaches us that IP's legal entitlements, and perhaps legal regulation in a more general way, possibly affect the message that the creators in a certain creative field wish to convey via their creations. A change in the legal entitlements alters not just the creator's rights, but possibly also the expressive features of her creativity. 
[Vol. 10:133

This article progresses in several stages. Part I sets the scene. It explicates the term drag queen, gives a short historical background, and outlines the structure of the Israeli drag domain, including delineating its subject matter and the queens' incentives for creation. Part II explains why copyright law and other IP laws fail to protect the queens' intellectual creations. Part III details the main empirical findings. It describes the drag domain's set of IP norms, namely norms against appropriation and norms regarding attribution. Part IV addresses the question of what makes the drag domain's social norm system function well and what its possible disadvantages are. It also explores the ideas and messages that the drag domain seeks to convey and the meaning of those messages with regard to the IP discourse. Part V concludes by suggesting that the drag domain offers important lessons for the IP discourse: it illustrates the benefits of utilizing the relations between creators and their audience as a means to protect creators' intellectual property; it demonstrates that juridification potentially influences both the tools a creator has to protect her intellectual property as well as the ideas she wishes to express via her intellectual creativity; and it proposes that focusing on prevention of appropriation rather than on punishing appropriators, yields less appropriation and consequently lower adjudication costs.

\section{PART I-SETTING THE (DRAG) SCENE}

\section{A. Drag Queens-Definitions}

The term drag queen warrants clarification. The first half of the term is often described as, or associated with, female impersonation, transvestitism, being a "gender bender," or cross-dressing. ${ }^{5}$ However, the drag queens interviewed for this study and research regarding drag usually do not identify with, or even object to, the said descriptions. ${ }^{6}$ In their view, drag is not simply female impersonation or meddling with the borders of gender, but rather it is a rich world of creation and identity. ${ }^{7}$ The second component of the term, queen, expresses the theatrical and sensational component of drag. Drag queens, on and off stage, assume a completely different attitude, aesthetic, and persona than their real-life self. ${ }^{8}$ From

5 Joshua T. Barnett \& Corey W. Johnson, We Are All Royalty—Narrative Comparison of a Drag Queen and King, 45(5) J. LEIS. RES. 677, 678 (2013); Dana Berkowitz, Linda Belgrave \& Robert A. Halberstein, The Interaction of Drag Queens and Gay Men in Public and Private Spaces, $52 \mathrm{~J}$. HomoseX. 11, 13 (2008); Nimrod Ben-Cna'an \& Danny Kaplan, Performing Drag in Israel: Standing on High-Heels, 159-60 Bamah: Drama Q. 81, 83 (2000) [Hebrew]; Peter Underwood, Life's A Drag DanNy La Rue AND THE DRAG SCENE 18 (1974)

6 Barnett \& Johnson, supra note 5, at 679; Steven J. Hopkins, "Let the Drag Race Begin": The Rewards of Becoming a Queen, 46 J. HomoseX. 135, 137 (2004).

7 Carsten Balzer, The Beauty and the Beast, 46 J. Homosex. 55, 61 (2004).

8 See Barnett \& Johnson, supra note 5, at 679. 
everyday ordinary males, the queens become celebrated divas whose personas are extravagant and ostentatious. Although it is difficult to locate a comprehensive definition of the term drag queen, for the sake of this article, I will use the term to refer to a biological male who dresses up in female attire in order to perform publicly with the audience realizing that the performer is a biological male.

Drag is unique in the sense that, unlike other performing arts, the performer's persona is attached to the performer so long as he is "on drag." Namely, even off-stage he will remain the drag queen that he is, until he resumes his regular male self. One interviewee explained:

In theater, when Gila Almagor [a famous Israeli actress] goes off stage, even if she still has her makeup and costume on, people will refer to her as Gila, not the character she just portrayed. Also, people will talk about Gila's performance. In drag, I am [the drag persona] even off-stage and until I get home. People don't talk about [my] performance but about [my drag persona]'s performance.

Moreover, the drag personas have "a life of their own." That is, they "live" independently from the person behind them. ${ }^{9}$ For example, most queens have their own social network pages in which they write their thoughts and share their everyday experiences. Many of them have their own (male) social network page parallel, in which they share other (many times, unrelated) thoughts and experiences. ${ }^{10}$

\section{B. A Short History of Drag in Israel}

Tracing the genesis of the Israeli drag scene is almost a mission impossible. ${ }^{11}$ There is no recorded history of the scene, and there is

9 This is somewhat similar to the function of pseudonyms in the extra-legal domain of female roller derby pseudonyms. Once a skater secures a name it becomes her sole identification in the roller community. Others in the community will refer to her according to her pseudonym even in social events and online. See Fagundes, supra note 3, at 1107.

10 Interestingly, a few months after the field study for this article was conducted, one of the queens drew my attention to a change in Facebook's policy regarding the use of drag names (over the performer's legal name) according to which only legal names (and no drag names) can be used henceforth on the social network's pages. See Amanda Holpuch, Facebook Under Fire From Drag Queens Over 'Real-Name' Rule, THE GUARDIAN (Sep. 13, 2014), http://www.theguardian.com/ technology/2014/sep/13/facebook-under-fire-drag-queens-real-name-rule; Andrew Griffin, Facebook's Name Policy Angers Drag Queens, THE InDEPENDENT (Sep. 14. .2014), http://www.independent.co.uk/ news/facebooks-name-policy-angers-drag-queens-9731904.html. However, a few days later, due to the queens' protest, Facebook apparently apologized and canceled the new policy. See Amanda Hopuch, Victory For Drag Queens As Facebook Apologises For 'Real-Name' Policy, ThE GUARDIAN, (Oct. 1, 2014), http:/www.theguardian.com/technology/2014/oct/01/victory-drag-queens-facebook-apologisesreal-name-policy; Reed Albergotti, Facebook Changes Real-Name Policy After Uproar From Drag Queens, WALL ST. J., (Oct. 2, 2014), http://online.wsj.com/articles/facebook-changes-real-name-policyafter-uproar-from-drag-queens-1412223040.

11 Roger Baker gives an account of drag queens throughout the centuries and the development of 
disagreement as to when it started. ${ }^{12}$ Although female impersonation by male actors was part of the Jewish theater from the early twentieth century, ${ }^{13}$ it was not until 1982 that drag shows, as such, were performed on stage in a club in Tel-Aviv. ${ }^{14}$ However, the performers were amateurs who performed irregularly and neither saw nor established themselves as "proper" drag queens, and this expedition soon ended. Only in the early 1990s did drag queens first start performing on stage regularly. ${ }^{15}$ The awakening of the drag scene in the early 1990s is attributable, inter alia, to the growing influence of Western entertainment culture in Israel and to the growing confidence of the Israeli gay community. ${ }^{16}$ The drag scene developed with the first queens performing in both gay and straight clubs. ${ }^{17}$ The first drag queen who established herself as such was Diva D, who started performing in the early 1990s in gay and straight clubs in Jerusalem. ${ }^{18}$

Shortly thereafter, four graduates of the Tel-Aviv University's theater class established the first Israeli drag-band. They named themselves The Pessya Girls. In March 1995, following their success in gay clubs, The Pessya Girls began performing what they called "The First Zionist Drag

the genre, writing, "[s]he emerges from the mists of time and threads her way through the histories of all cultures and all nations. She is present at solemn religious rites and kicks up her skirts at anarchic celebrations..." ROGER BAKER, DRAG 24 (1994). Laurence Senelick also provides a detailed anthology of the development of drag from Shamanism via the Orient, Middle-age theater until modern times. Laurence Senelick, The Changing Room—Sex, Drag and Theater (2000). Michael Moore provides similar accounts in DRAG! MALE and Female IMPERSONATORS ON STAGE, SCREEN AND TELEVISION (1994). Moore particularly notices that "[d]ressing up in drag became part of gay bars, clubs, dances and balls since their inception unknown time ago."

12 For example, there is disagreement over whether certain performances can be considered proper drag shows or merely performances that include female impersonation. It seems that there is no recorded history due to the fact that the gay community, at the time when shows started, was a fragile and prosecuted minority community that kept a low profile, and, for obvious reasons, avoided documentation.

13 To the best of my knowledge, the 1878 Yiddish play The Witch of Botoşani (Di Kishefmakhern) by Abraham Goldfaden is the first Jewish play in which female impersonation was part of the play. The phenomenon of male actors playing female roles, however, was long established in theatre. See Moore, supra note 11; Senelick, supra note 11; and Baker, supra note 11.

14 See Dan Yanovitz, Stepping Stones in the History of the Israeli LGBT Community (Dec. 3. 2006), http://www.glbt.org.il/he/history/articles.php?articleID=408 [Hebrew].

15 Cnaan \& Kaplan, supra note 5, at 82. According to the head of the Israeli Drag School in the Tel-Aviv Gay Community Center, there were also transvestite striptease shows for a short time in the city of Haifa in the 1960s. Later on in the late 1980s a German drag queen called Chris Crazy performed in Tel-Aviv and Jerusalem.

16 Ben-Cna'an \& Kaplan, supra note 5, at 82-83.

17 Id. at $84-85$.

18 Diva D and another queen were engaged in a dispute over the title of "Israel's first drag queen." This was a public dispute that took place on social media, with both queens trying to prove they were the first proper drag queen in Israel. In the end, Diva D's opponent conceded that Diva D was her predecessor. Diva D is considered the most senior queen. Many, herself included, refer to her as "the ancient" queen, and a major part of her drag persona is that of an old powerful female monarch. Diva D is still very active today. 
Show Ever"; ${ }^{19}$ the show was extremely popular with the general public, and the band started appearing on national television. ${ }^{20}$ In 1999, one of the Pessya Girls, Isaac Cohen, who performed under two drag personas, Hassida Worthwhile and Gladis the Iraqi, left the group to pursue a solo career. This resulted in a dispute between the four group members. This dispute, to the best of my knowledge, is the only dispute between queens in Israeli drag history that involved formal litigation. ${ }^{21}$ The remaining queens sought an injunction preventing Cohen from using the drag personas of Hassida and Gladis. They claimed that these personas were intellectual property owned by the group and did not belong to Cohen himself. Cohen filed a counterclaim asserting that the remaining queens be prevented from using the name Pessya Girls, as it was the name of the group of all four queens and not just the three. ${ }^{22}$ In response to the legal battle, the three remaining queens competed in the 2000 Israeli Song Festival as The Band Whose Name Cannot Be Mentioned. ${ }^{23}$ The queens' legal battle proceeded to arbitration and ended in an agreement under which Cohen was prohibited from using the drag names Hassida Worthwhile and Gladis the Iraqi, and the queens were allowed to keep the name Pessya Girls. ${ }^{24}$ Cohen, it should be noted, used all the features of his drag personas in his solo career but under different drag names.

From the late 1990s and throughout the first decade of the twenty-first century, the drag scene rapidly expanded and flourished. Regular drag nights in Jerusalem and Tel-Aviv were (and continue to be) performed. Drag became more professional with queens regularly performing in different venues. At the same time, a lively amateur scene developed around the professional queens, and the popularity of amateur drag nights is ever-growing. The queens established themselves as notable figures in the gay community. They were invited to host the Jerusalem pride and tolerance parade, and they became sought-after guests at parties and other social, usually gay, events. Over time, regular drag performances expanded to other cities in Israel. Individual queens and drag bands started appearing

19 Yanovitz, supra note 14.

20 Initially on a one-time basis in the comic intervals during the broadcasting of the Israeli nationals for the European Eurovision song contest, and later in a permanent slot in a popular Saturday night talk-show.

21 This information was confirmed by the head of the Israeli drag school in the Tel-Aviv Gay Community Center.

22 Isaac Danon, Isaac Cohen will remain a Pessya Girl, GLoBES (July 11, 1999), http:// www.globes.co.il/news/article.aspx?did=161718 [Hebrew].

23 The band's profile is available on the Israeli music site Mooma at http://mooma.mako.co.il/ Biography.asp?ArtistId=1905 [Hebrew]. The Song Festival's website is available at http://tpeople.co.il/ hebrew/festival/FZ.asp [Hebrew].

24 The Pessya Girls Are Reborn, Yardena Ja'ala to a Better World, CHANNEL 10 NeWs (Sept. 3, 2000), http://news.nana10.co.il/Article/?ArticleID=13946 [Hebrew]. 
in private and corporate parties, which serve as an ever-increasing income and employment source for the queens. A drag wiki was launched. ${ }^{25} \mathrm{~A}$ television mini-series whose main plot revolved around drag was aired in 2009 and gained success. ${ }^{26}$ Drag bands started appearing in theaters, gaining notable media coverage. In 2012, the Israeli Drag School in the Tel-Aviv Gay Center opened its gates. Today, there are an estimated twenty to twenty-five retired or inactive queens and an estimated twentyfive active queens. ${ }^{27}$

\section{Methodology}

In all, eleven drag performers were interviewed, accounting for almost half $(\sim 4 \%)$ of the estimated number of active Israeli drag queens. I initially planned to interview drag queens only. However, after interviewing several queens, the role of users (i.e., non-queens) became evident. Although the main focus of the study remained the queens' view of the IP norms, I nevertheless decided to conduct three interviews with venue owners in order to validate the data received from the queens regarding their role. It should be noted that one of the venue owners was also a drag queen. I developed a semi-structured in-depth interview instrument to identify the norms used by the queens in order to protect their intellectual labor. ${ }^{28}$ All questions were open-ended. ${ }^{29}$ Interviews lasted between thirty minutes and two hours, averaging approximately one hour.

25 The drag wiki is available at http://gevald.a.wiki.co.il/index.php/\%D7\%A7\%D7\%98\%D7\% $92 \% \mathrm{D} 7 \% 95 \% \mathrm{D} 7 \% \mathrm{~A} 8 \% \mathrm{D} 7 \% 99 \% \mathrm{D} 7 \% 94: \% \mathrm{D} 7 \% 93 \% \mathrm{D} 7 \% \mathrm{~A} 8 \% \mathrm{D} 7 \% 90 \% \mathrm{D} 7 \% 92$ [Hebrew]. The wiki includes even the most amateur and one-timers. As of January 2015, it looks as if the site was not updated for quite some time.

26 See Gilad Padva, Always the Same Dream? Kitsch, Camp and Sexuality in Eytan Fox's Films, 39 TERMINAL - 21st CENTURY ART JOURNAL 21, 23 (2009) [Hebrew].

27 Queens do not usually declare their retirement. Thus, it is hard to know if a queen considers herself retired or just temporarily inactive. For the sake of this study, queens that did not appear more than four times over the last year were considered inactive or retired. Alongside the vibrant queen scene, there used to be a less active, yet notable, drag king scene. Drag kings, for the purpose of this article, are biological females who dress up in male attire for the purpose of performing, with the addressees of the performance realizing that the performer is a biological female. The drag king scene ceased around 2012 with the closure of a lesbian venue in Tel-Aviv that hosted drag king shows. Today there are no active drag kings. There are an estimated ten to twelve inactive or retired drag kings. There is also a male - to female - to male drag scene, i.e., queens who as such dress up as males and perform songs sung by males.

28 All interviewees were guaranteed full confidentiality, and gave verbal consent to participation. Most interviews were recorded and transcribed. Several interviewees preferred not to be recorded, in which case I wrote down the content of their interview on paper instead. All interviewees were interviewed off-drag. Namely, the queens were interviewed as their male-selves and not as their drag personas.

29 See Kathy Charmaz, \& Linda Belgrave, Qualitative interviewing and grounded theory analysis, in THE SAGE HANDBOOK OF INTERVIEW RESEARCH: THE COMPLEXITY OF THE CRAFT 350 (Jaber Gubrium, James A. Holstein, Amir Marvasti, \& Karyn McKinney, eds., 2d ed., 2012). 
All interviews were conducted one-on-one, ${ }^{30}$ in person, with the interviewees determining the location of the interview. ${ }^{31}$ Some interviewees were recruited via independent contacts and then via chainreferral sampling. ${ }^{32}$ Others were recruited directly upon approach after a show or via social media. No formal follow-up interviews were conducted. However, in some cases after the interviews I unintentionally met the queens at their or their peer's shows. Several of them commented on, or demonstrated, issues that were brought up in the interview. The data obtained in that manner did not stray from the data given in the formal interviews, and was not recorded. For the qualitative analysis I employed the Grounded Theory method. ${ }^{33}$ The research reached satisfactory saturation and verification. ${ }^{34}$

\section{The Structure of the Drag Domain}

The unique characteristics of the drag domain - the social and physical environment in which the creative process takes place, the audiences that watch the shows, as well as the subject matter of the drag domain-are key factors in understanding the social norms that regulate the protection of the queens' intellectual creativity. As discussed below, the queens wisely, even if unintentionally, take advantage of many of these unique characteristics in the protection of their intellectual creations.

\section{D (I). The Environment of the Drag Domain}

The drag domain operates in an environment that has distinct physical

30 Except for one case, which was done jointly with two queens at their request.

31 See Hanna Herzog, Interview Location and its Social Meaning, in THE SAGE HANDBOOK OF INTERVIEW RESEARCH: THE COMPLEXITY OF THE CRAFT 207 (Jaber Gubrium, James A. Holstein, Amir Marvasti, \& Karyn McKinney, eds., 2d ed., 2012).

32 The Sage Encyclopedia of Qualitative Research Methods 191 (Lisa Given, ed., 2008).

33 I approached the data collection stage with no hypothesis in mind as to the methods by which the queens protect their intellectual creations, if at all. As mentioned, the interviews were semistructured and open ended. The key points from the interviews that I perceived as pertinent to the drag queens' social practices of IP protection were developed into codes. These codes were refined through iterative reading and then conceptualized in an IP setting. See Kathy Charmaz, Constructing Grounded Theory (2d ed. 2014); see also Charmaz, \& Belgrave, supra note 29.

34 In order to ensure saturation and verification (i.e., that a sufficient amount of queens both qualitatively and quantitatively were interviewed) I ensured variation in the interviewees' age range (the youngest was under twenty, the oldest over fifty); the duration, in years, of performing as an active queen (ranged between just one year to over fifteen years); status in the drag hierarchy (as defined in part D (III) below); and the frequency of performance (between six-seven times a year to twice-thrice a month). See Greg Guest, Arwen Bunce \& Laura Johnson, How Many Interviews Are Enough? An Experiment with Data Saturation and Variability, 18 Field Methods 59 (2006); Ben Beitin, Interview and Sampling: How Many and Whom, in The SAGE HANDBook of InTERVIEW ReSEARCh: The COMPleXity of the CRAFT 243 (Jaber Gubrium, James A. Holstein, Amir Marvasti, \& Karyn McKinney, eds., 2d ed., 2012). 
[Vol. 10:133

and social features. Four main features are clearly reflected in the IP norms that have developed in the Israeli drag domain: (1) the engagement of the consumers and services providers; (2) the closeness of the group and the familiarity amongst the queens; (3) the identity of the potential infringers; and (4) the venues in which the queens perform.

Drag, as a phenomenon, is by no means constricted to the gay community. The drag scene is alive and kicking well outside the pink ghetto. $^{35}$ In fact, in monetary terms, most of the pecuniary rewards come from performances in front of the general public. Notwithstanding, drag queens clearly operate socially within the gay community. ${ }^{36}$ Their social capital, ${ }^{37}$ which is substantially more important to the queens than any other form of reward, comes mainly from the gay community. The performances that are the more prestigious and the more sought after, are, by and large, performed and aimed at the gay community. Many of the interviewees mentioned that the shows of the highest esteem are the ones that are able to attract the gay audience in a recurring manner. In this regard, it is worth mentioning that the gay community is not just the target of most of the performances, it is also the queens' social habitat, because, to the best of my knowledge, all Israeli queens performing today openly identify themselves as gay. Moreover, the queens have an esteemed and wellrespected position within the gay community. ${ }^{38}$

The viewers are not the only user group in the drag domain. Another important user group is that of related services providers, namely, intermediaries who provide the queens with the goods they need to put on a show or to set the stage upon which they perform, like DJs, club or other venue owners, dress tailors etc. The related services providers in Israel are usually part of the gay community and have close social ties with the queens.

As a rule, the queens are very well acquainted with one another and can be described as a close-knit group. ${ }^{39}$ This is a very small community of approximately twenty-five queens that are subject to repeat interaction. The queens are, to a very great extent, dependent on each other in the technical sense. For the sake of putting on their show they lend clothes and wigs (which are costly), help one another to put on the makeup and get dressed,

\footnotetext{
35 See Ben-Cna'an \& Kaplan, supra note 5, at 82; Hopkins, supra note 6.

36 See Ben-Cna'an \& Kaplan, supra note 5, at 82; Barnett \& Johnson, supra note 5; Hopkins, supra note 6.

37 See Pierre Bourdieu, The Forms of Capita, in HANDBOOK OF THEORY AND RESEARCH FOR THE Sociology OF EduCATION 241 (J. G. Richardson, ed. 1986).

38 See C.F. Mark Kiss, CJ Bishop, Todd G. Morrison, Damien M. Rushe \& Jacqueline Specht, The Association between Gay Men's Stereotypic Beliefs About Drag Queens and Their Endorsement of Hypermasculinity, 61 J. HOMOSEX. 554-55 (2014).

39 See Robert Ellickson, ORder Without LAW 177 (1991).
} 
host each other on their shows, and promote each others' future events. This familiarity and interdependence allows for a very effective enforcement mechanism in cases of appropriation, as will be described. The familiarity is, however, not just about technical cooperation. Most of the interviewees described themselves as part of a family, a community of creators that share certain goals and convey a joint message. ${ }^{40}$

Drag is a live performing art. These two elements - the live show and the fact that it is a performing art-have significant ramifications in the context of the drag domain. Similar to other performing arts, such as theater or magic shows, drag viewers ostensibly prefer live shows. Interviewees indicated that recorded performances are of little value to viewers. This means that recording the shows and exploiting them, like posting them on the Internet, is of relatively negligible significance to the queens. Moreover, the queens indicated that they themselves often upload their performances to YouTube so that others may view for free. ${ }^{41}$ The shows being a live performing art means that potential copyists and appropriators come almost exclusively from within the cadre of creators (i.e., the queens). These two elements stand in stark contrast to many other extra and intra legal domains of IP in which the live-show-factor has no significance or in which copyists and appropriators do not necessarily come from within the group of creators. For example, motion pictures, an intralegal domain, lack the live factor and can be copied by anyone, not necessarily a peer. Graffiti, an extra-legal domain, ${ }^{42}$ can be, and in fact is, appropriated by people outside the cadre of creators, such as art-book publishers or clothes manufacturers who print appropriated graffiti art images on shirts they produce. ${ }^{43}$

The venues in which the drag shows take place differ significantly from one another. This is not only with regards to the clientele, but also in the prestige and recognition they bring to the performers in them. The venues and venue owners are often key factors to the regulation of the drag domain. The queens rely on the venue owners' cooperation in enforcing

40 Similarly, many other studies of extra-legal domains emphasize the importance of belonging to a community to the creators. E.g., Sprigman \& Oliar, supra note 3 at 1816; Fauchart \& Von Hippel, supra note 3 at 187; Perzanowski, supra note 3, at 984.

41 This is done for many reasons, such as promotion and outreach, but also as an important tool to claiming priority over the number (i.e., the song and the accompanying moves) as belonging to the queen who first posted the performance.

42 See Roundtree, supra note 3.

43 Id. at 960. Roundtree describes the case of a German graffiti artist named Cantwo, who was surprised to discover that in the 2008 Olympic Games the Spanish synchronized swimming team competed in swimsuits emblazoned with a graffiti character he claimed to have created in 2001. See Markus Balser, Cantwo Says “Can Not!” to Spanish Swimmers, Wall St. J. L. Blog (Sept. 9.2008), http://blogs.wsj.com/law/2008/09/09/cantwo-says-can-not-to-spanish-swimwear/. 
some of the anti-appropriation norms. ${ }^{44}$ The venues in which the shows take place, from the less to the more prestigious (by and large), consist of the following: (1) Bachelorette and birthday parties - usually performed by a single queen, who puts on a special show for the bride-to-be or the birthday celebrator and their friends. Although a relatively significant source of income, it is usually less-desired by the more senior queens. (2) Private firm parties - usually performed by two to three queens (depending on the hiring firm's size), and usually done on a firm's "fun day" for its employees. There is an extremely high demand for shows in firms' Purim parties, ${ }^{45}$ and in events marking femininity (such as mother's day, international women's day, and firms' women worker's day). This is a more prestigious standing and is practiced by senior and junior queens alike. (3) Gay party lines - party owners invite queens to steam up their parties, queens attract clientele and party producers hire them to come and sometimes even to perform during the parties. This is considered a prestigious role and is usually occupied by the more senior queens. (4) Designated drag performances - open-to-the-public drag performances in one of the gay venues. These are almost always hosted by at least two senior queens who usually invite other queens to perform as well. (5) The gay pride parade - the annual parade in Tel-Aviv, one of world's largest and most renowned, ${ }^{46}$ is party themed and has floats on which the most senior queens, sponsored by private entities, dance and cheer (other queens show up, but do not ride on the floats). The parade in Jerusalem is more political. It ends up in a gathering in front of the Israeli parliament, and in it, politicians and community leaders give political addresses. Its on-stage hostess is a senior queen who might invite other queens to perform, which is considered an honor. (6) Theater-performing a full drag show in theater is a very prestigious, so far reserved only to drag-bands composed of the most senior queens. (7) Television-reserved only to the most senior queens; there were a few productions involving drag shows on national television. ${ }^{47}$

These four factors - the users, the communal close-knit familiarity, the infringers, and the venues-constitute the drag domain's social and physical environment. Each of these factors is well-reflected in the drag domain's IP norms, as described below.

44 Further discussion on the role of venue owners is found in Part 3(A)(III) of this article.

45 A Jewish holiday that includes wearing masks and costumes, consuming alcoholic beverages, and public celebrations.

46 See, e.g., Harriet Sherwood, Tel Aviv's Gay Pride Parade Draws Thousands to the City, THE GuARDIAN (June 10. 2011), http://www.theguardian.com/world/2011/jun/10/tel-aviv-gay-pride-parade; Tel Aviv declared world's best gay travel destination, HAARETZ, (Jan. 11. 2012), http:// www.haaretz.com/travel-in-israel/tel-aviv-declared-world-s-best-gay-travel-destination-1.406699.

47 Two notable drag bands that appeared on television were the Pessya Girls and a band called Holy Wigs. See Padva, supra note 26. 


\section{D (II). The Queens' Incentives}

The question of incentives in the drag domain, i.e., why performers choose to perform drag, illuminates important lessons regarding IP's incentive theories and highlights the importance of social capital and personal rewards to creators. None of the interviewees mentioned pecuniary rewards as an incentive for performing. Moreover, a substantial portion of the interviewees mentioned that they in fact lose money over the shows, as the income does not cover the investment. Makeup, costumes, and wigs are costly and each show requires changing all of them several times, not to mention the substantial amount of time needed to practice before a performance. ${ }^{48}$ Even for most of the queens that perform regularly, performances are not their main source of income. In fact, in Israel drag is the single source of income to just one queen and the major source of income to approximately three more. ${ }^{49}$ This adds up to only about onesixth of all queens relying on drag as a substantial source of income. ${ }^{50}$

There are different motivations for performing drag. In addition, there seems to be a difference between initial motivations and the motivation to keep on performing drag. Some queens have a single, or one major, incentive for performing, while others have a combination of a few different motivations.

Expression of identity-Most queens indicated that their drag persona expresses aspects of their personality or sexuality that are not expressed in their everyday lives. As one interviewee said, "[My drag persona] is free from social constraints; she can curse, she dances, she speaks her mind and doesn't give a shit as to what others think, her personality is extremely extravert; but in everyday life I am a well-educated, shy, and very introvert person." Another interviewee mentioned, "Usually, I never have the courage to hit on anyone, but [my drag persona] walks right up to the hottest guy in the room and orders him to buy her a drink." Drag allows the performers to question the borders of gender and sexual identity and to explore the borders of their sexuality; ${ }^{51}$ it has an escapist dimension; ${ }^{52}$ it

48 Many of the studies of the extra-legal domains emphasize that non-monetary incentives are the main vehicle for invigorating creation in different domains. Interestingly, in the roller-derby pseudonyms domain pecuniary rewards play no visible part whatsoever, as it is a non-competitive sport, see Fagundes, supra note 3 at 1141. Moreover, in the graffiti domain, like the drag domain, creators actually many times lose money over the creation, see Roundtree, supra note 3, at 974.

49 This datum was presented by many of the interviewees and was confirmed by some of the subjects of this assertion. This assertion is strengthened by the fact that, to the best of my knowledge, only one queen does not have a day job.

50 A similar observation is presented by Steven P. Schacht with regards to drag queens in North America. See Steven P. Schacht, Four Renditions of Doing Female Drag: Feminine Appearing Conceptual Variations of a Masculine Theme, 6 GENDERED SEXUALITIES 157, 169 (2002).

51 Similar observations were made by ALANA KuMBIER, One Body, Some Genders: Drag Performences and Technologies, in THE DRAG KING ANTHOLOGY 191 (Donna Troka, Kathleen Lebesco 
allows the performers to be who they want to be; ${ }^{53}$ and it gives the performers the courage to negotiate their social and personal phobias. ${ }^{54}$ All of these reasons were noted by many interviewees as very important motivations to performing drag. ${ }^{55}$

Confirmation, fame and status-Queens enjoy high regard within the gay community. The senior queens enjoy celebrity status and are admired divas. Many interviewees mentioned the will to receive attention and the desire to gain fame and glory as important motivations for becoming a queen. ${ }^{56}$ One interviewee colorfully expressed this common notion, explaining, "We're all bitches of the spotlight. We want to be admired. We breathe applause and attention."

Fun and enjoyment-Many interviewees mentioned the personal feeling of enjoinment they get from performing drag. One of the interviewees nicely summed this point, stating, "Being a queen is the greatest fun. You can do what you want whenever you like, you account to nothing, it's a great thrill."

Personal satisfaction-Satisfaction, as an incentive to drag creation, is reflected in two major ways: first, immediate satisfaction in succeeding in entertaining a large crowd of people $;{ }^{57}$ and second, intellectual satisfaction that the performer gets from perfectly impersonating a female or a certain figure.

Political motivation - Many queens, but notably a few senior queens, mentioned the possibility of mobilizing social and political change regarding LGBTQ rights via drag. ${ }^{58}$ "In my performances," one queen

\footnotetext{
\& Jean Noble, ed. 2002).

52 See also Hopkins, supra note 6, at 140.

53 Id.; see also Senelick, supra note 11, at 10.

54 See Hopkins, supra note 6, at 141; see also Schacht, supra note 50, at 170.

55 An interesting comparison is to the role of the extra-legal domain of roller derby pseudonyms for the derby girls. As Fagundes holds, roller derby names serve an identity concealing function since they separate a skater's derby persona from her real-life identity. They allow the skaters to develop identities within the roller derby world. He holds that: "Many participants are drawn to derby because it provides a welcome contrast to the everyday grind and provides a space that permits them to explore aspects of their personalities that cannot find expression in their daily lives", Fagundes, supra note 3, at 1111,1105

56 See e.g., Hopkins, supra note 6, at 140; Balzer, supra note 7, at 61; Schacht, supra note 50, at 161-162, 170; Kiss et al., supra note 38, at 555, 562; Senelick, supra note 11, at 362. Fame was identified by Roundtree as one of the four "core values" of the extra-legal domain of graffiti, and a decisive incentive to creation. See Roundtree supra note 3, at 984. See also, with regard to rollerderbies, Fagundes, supra note 3, at 1141.

57 See Barnett \& Johnson, supra note 5, at 679. Similar observations with regards to stand-up comedy were made by Sprigman \& Oliar, supra note 3, at 1816.

58 See also Senelick, supra note 11, at 470. Senelick demonstrates that in other places around the world drag was used not only as a political tool in relation to LGBTQ issues, but also as a tool to raise awareness to other political, cultural and human rights issues. Senelick inter alia gives the example of the South-African drag queen Evita Bezuidenhout (of a "prominent Jewish Afrikaner
} 
mentioned, "I give fellow people in the community strength to cope with the social hardships they encounter." She emphasized that this is particularly important for transgender and queer people "who suffer at the hands of society at large and also from gay men who treat them wrongly no less, and sometimes even more, than the general public." Many queens emphasized that drag mitigates homophobic prejudices and allows for them to speak out to audiences that are usually not open to hearing about LGBTQ issues. $^{59}$

Community and social acceptance-The community of queens is a small cluster, a "close-knit group." 60 As mentioned, they all know one another and treat each other as "sisters," "mothers," and "daughters." 61 The feeling of belonging to a community (unrelated to the greater gay community) is a strong motivation for drag creation. ${ }^{62}$

\section{D (III). The Social Structure}

Similar to observations made in other studies of drag communities, ${ }^{63}$ the study revealed that there is a strict social ladder and hierarchy amongst the Israeli drag queens. The hierarchy is rigorously respected and very rarely contested. I roughly categorize the queens into the three following categories: senior queens, established queens, and junior queens. (1) Senior queens are individuals who have been involved in the drag scene for usually a few years, who have proven success, and who are acclaimed or highly esteemed by other queens and the audience. Often the senior queens control a specific venue, or (especially in smaller towns) even a geographical territory. The senior queens are sometimes called the divas, or, by their protégées, "mother drags." They are respected amongst the performers and the audience, and some are known in the general, non-gay community. (2) Established queens are queens who have been performing for typically several years but have not yet established themselves as senior queens. They are usually well-known but not as famous as the senior queens. They might control a venue, although this is rare. Some of the established queens are the up-and-coming stars of the drag scene, but some are those who have not been able to establish themselves as senior queens. (3) Junior queens are amateurs, or newly introduced queens, that have a

\footnotetext{
family") who brought up issues regarding apartheid. See Senelick, supra note 11 at 474-78.

59 Compare Senelick, supra note 11, at 469-471 (noting that in the US during the 1980s, drag was "a tool of protest" regarding the AIDS pandemic), with Ben-Cna'an \& Kaplan, supra note 5, at 82.

60 Ellickson, supra note 39, at 177. Senelick, supra note 11, at 377-402 (demonstrating that historically in America, from as early as the beginning of the twentieth century, drag performers tended to operate in close-knit groups).

61 See also Hopkins, supra note 6, at 145.

$62 I d$. at 140.

63 See Hopkins, supra note 6, at 139-140; Schacht, supra note 50, at 169.
} 
limited status. Some of the junior queens are students in, or recent graduates of, the Israeli drag school in the Tel-Aviv Gay Community Center; ${ }^{64}$ some are the protégées of the senior queens, which nourish their "daughter" or "baby" drags (many times referred by their peers as the "puppies" or "bitches" of the mother drag); and others are individuals trying to make it on their own. By and large, the drag status does not depend on the quantity of the performances being carried out by the queen, but rather on reputation, talent, and popularity with the audience and peers.

The nature of a drag performance almost inherently requires the queens to perform in groups of at least two-one queen will entertain the audience while her peer changes her clothes and wig and vice-versa. As a rule, queens are individual performers and do not belong to a permanent ensemble, though they often match-up together for a specific show. Nevertheless, some queens do belong to drag-bands. There are two models of drag-bands: a permanent drag-band in which the queens always perform together and ad-hoc bands in which the members convene just for the sake of a specific show.

\section{D (IV). The Subject Matter}

The intellectual property which is the subject matter of the drag domain spans over a very wide range of proprietary rights. Unlike copyright law, the proprietary rights are not only limited to the actual intellectual creation of the queen, but they also incorporate ownership of what can be described as ideas or concepts. The incapability to own ideas is perhaps one of the most fundamental features of copyright law. Ownership of ideas or concepts is contrary to copyright law's very basic notions and is strictly prohibited. ${ }^{65}$ The subject matter of the drag domain is:

64 The school was opened in 2012 by one of the most senior queens. According to the school's founder and head-teacher, who was interviewed for this study, the school aims to equip its students not only with the tools needed to become the best in their profession (dressing, lip-syncing, make-up applying, dancing, etc.), but also to empower the students as individuals and to create a new generation of drag queens which see drag not merely as a comical venture, but as an art with an agenda. It should be emphasized that the "drag code" (see below) and the drag norms are given great consideration, and the young students are to be well-acquainted with them.

65 The Israeli Copyright Act, Copyright Act, 5768-2007, 2119 LSI 38 (2007) (Isr.), explicitly states in section 5 that "copyright in a work ... shall not extend to any of the following, however it shall extend to their expression: Idea ...." See Tel-Aviv University's unofficial translation from Hebrew of the 2007 Copyright Act at http://www.tau.ac.il/law/members/birnhack/IsraeliCopyrightAct2007.pdf. 17 U.S.C. § 102 (1990) clearly expresses this principle, stating "[i]n no case does copyright protection for an original work of authorship extend to any idea, procedure, process, system, method of operation, concept, principle, or discovery, regardless of the form in which it is described, explained, illustrated, or embodied in such work." See Mazer v. Stein, 347 U.S. 201 (1954) "[U]nlike a patent, a copyright gives no exclusive right to the art disclosed; protection is given only to the expression of the idea-not the idea itself." 
The drag persona - each queen develops a unique and very distinct drag persona, e.g., the desperate housewife, the stupid blonde, the neurotic Jewish mother, etc. The ownership of the persona is complete and together with the drag name is regarded as the strongest proprietary right.

The drag name - each queen has a unique name. Ownership of the drag name is absolute.

Numbers - a number is the performance of specific dance moves and pantomime while lip-syncing to the sounds of a particular played-back song. The ownership rights in a number include complete ownership of the dance moves and the pantomime, and, in most cases, the played-back version itself. For example, once a certain queen performed a drag routine to the sounds of Britney Spears' Oops I Did It Again, she became owner of the song's version as well as the dance routine. This means that if a peer wishes to perform to the sounds of Britney's Oops I Did It Again or wants to imitate the routine even if for a different song, she will require the owner's consent. As will be discussed, appropriation of either song or dance is strictly prohibited.

"Signature" songs-Most of the queens, particularly the senior and established ones, have a few songs which are strongly associated with them, as they have performed a few different numbers to their sound several times and created a clear affiliation with them. The queens enjoy complete ownership of these songs. This ownership includes new versions or covers. If, for example, a queen is affiliated with the song Holding Out For A Hero, then she owns Bonnie Tyler's original version as well as Ella Mae Bowen's acoustic version, Jennifer Saunders' version, etc.

Non-signature songs - a queen owns a song if she was the first to perform to its sound. However, this ownership is weaker than the ownership in signature songs, is not complete, and is limited in time, as will be elaborated below.

"Signature" singers - the ownership of this kind of subject matter is the premise of few senior queens only. Similar to signature songs, some senior queens are strongly associated with certain singers. Accordingly, the queen will have complete ownership of all that singer's songs, even if not previously performed by the queen, or any future songs this singer might release. For example, if Dolly Parton is a signature singer belonging to a certain queen, all past and future songs she produces belong to that queen. Interestingly, one of the interviewees, a senior queen, mentioned that she and a fellow senior queen shared Liza Minnelli as a joint signature singer with her peer owning all the songs Liza performed prior to 1986, and she owning all the songs produced, or that will be produced thereafter.

Jokes-A drag show usually consists of a few numbers. In the intervals between each number, the host of the show performs a short standup piece. Some of the stand-up pieces are signature pieces in which the 
ownership is complete, other pieces are fairly protected, and some jokes are clearly in the public domain. One of the interviewees gave the following example: A certain [senior] queen has a signature piece in which she invites a random viewer to compete in "the microphone challenge," a challenge in which the viewer attempts to place the queen's microphone in his mouth without his lips actually touching it. Appropriating this piece on stage is strictly prohibited. The "tourist in the crowd" routine-asking tourists to come on stage and mocking their home countries, is something every queen can do. It should be noted, however, that many of the jokes are improvised on-the-spot.

The drag domain's subject matter partially overlaps with that of IP law. Perhaps the most notable distinction between IP law and the drag domain is the lack of distinction in the drag domain between ownership of an idea or concept (e.g., a signature singer) and ownership of its expression (the dance performed to the sounds of that signature singer's songs). Both receive similar protection in the drag domain. Importantly, ownership of un-copyrightable elements such as a signature singer is not entirely a result of direct intellectual labor. The ownership is bestowed due to the intellectual labor invested in creating a strong affiliation with the signature singer.

The range of IP assets protected by the drag norms system (i.e., the subject matter) is clearly very broad. The drag domain does not merely protect a specific routine or song but provides protection to broader concepts, such as personas. The personas are given wide berth in terms of the scope of the right. This is unique to the drag domain vis-à-vis other extra-legal domains which do not protect similar broad concepts. For example, in the magic performances domain, only the magic trick is protected; in the stand-up comedy domain - the joke; roller-derby girls protect only the pseudonyms skaters use for their races, etc. ${ }^{66}$ In order to understand this phenomenon we must consider two questions: why the rights in the drag domain are so all encompassing and what allows the domain to keep them that way.

As to the question of why the rights are so all encompassing, two answers come to mind. First, a queen's persona is an expression of the creator's identity. The more unique the persona, the more personal value derived therefrom. Naturally, the queens will strive to ensure that their persona is given the widest protection possible. Second, the persona functions also as a trade-mark and as a marketing tool. Some audiences enjoy particular personas and prefer to see these on stage. So if, for example, two queens were to share the drag persona of the neurotic Jewish

66 See, respectively, Loshin, supra note 3; Sprigman \& Oliar, supra note 3; Fagundes, supra note 
mother, then they would also have to share the economic and social capital derived from those aficionados. Exclusivity over personas prevents such scenarios.

With regards to what allows this unique feature to exist, it seems that this is mainly due to the size of the drag domain. The Israeli drag domain is a small and close-knit community. The number of active queens, as mentioned, is approximately twenty-five performers. With only twenty-five personas subject to ownership (or a little more if we consider newly-retired queens) it seems that a new queen will still find a sufficient selection of personas from which she can choose and claim her own. Thus, she will not need to challenge this feature. This, seemingly, is a manifestation of John Locke's "proviso" regarding proprietary rights. ${ }^{67}$ According to the proviso one may legitimately acquire property rights by mixing her labor with resources held "in common" if, and only if, after the acquisition, "there is enough and as good left in common for others."68 Other extra-legal domains are significantly larger than the drag domain and ostensibly lack the ability to promise that as much and as good is left for others. ${ }^{69}$

The structure of the drag domain-its social dimension, physical environment, the audience, the queens' incentives, and the subject matternaturally influences the norms that regulate the domain. It can explain the two main questions that this article explores: why IP laws are, by and large, irrelevant to the regulation of the drag domain, and why the alternative norms that regulate it have evolved into the system described here. I turn to these two questions in the following sections.

\section{PART II-DRAG QUEENS AND FORMAL IP LAW}

\section{A. Barriers to the Use of Copyright Law}

Drag queens do not rely on IP law for the protection of their intellectual creativity. There is no singular explanation as to why that is. In the following section, I suggest that the reasons include doctrinal barriersIP law's narrow protection for derivative works, its originality requirement

67 John Locke, Two Treatises of Government, Second Treatise, s. 26, available at socserv2.socsci.mcmaster.ca/econ/ugcm/3113/locke/government.pdf.

68 Id.; see also Fisher, supra note 1; Herman Tavani, Locke, Intellectual Property Rights, and the Information Commons, 7 ETHICS \& INFO. TECH. 87 (2005).

69 The roller derby pseudonyms domain is a good example. Fagundes holds that in the derby world "not all names are created equal. Even if there is an infinitude of possible names, only some of those names will suit a skater's personality and style, so that a world in which skate names must be unique may well cause a newer skater to experience a much lower chance of being able to claim a name that truly suits her." See Fagundes supra note 3, at 1112-1113. It will be interesting to see how the drag norms system might adapt and respond to a possible growth in numbers which will require a more tolerant regime towards similarity (as not enough and as good will remain in the public domain). Time will tell. 
and its prohibition on protection of ideas - as well as practical barriers.

1. Derivative Works and the Originality Requirement

A derivative work is defined in the Israeli Copyright Act as "the making of an original work which is substantially based upon another work." ${ }^{\prime 70}$ The law grants copyrights to the creator of an original derivative work. It seems possible to suggest that the numbers performed in the drag shows might be considered derivative works. If so, they ostensibly have the capacity to enjoy copyright protection. However, the protection for derivative works does not confer the derivative creator with exclusive ownership over the preexisting original work. The preexisting work remains the first owner's, or, if it is in the public domain, everyone can use it. Put in legal terms, drag performances are a dramatic work that publicly performs and uses someone else's musical work, often in an adapted manner. Thus, only limited dramatic aspects-the aspects that are the queen's independent original work - can be protected. However, the queens do not settle for this. For the queens, exclusivity over the song visà-vis other drag queens is crucial. Ownership of the dramatic aspects without exclusivity over the preexisting song that accompanies them is meaningless. Thus, legal protection as derivative works, merely for the dramatic aspects, is of very little value for the queens. This rule applies only among the queens, rather than vis-à-vis the original owner or other, non-queen users. ${ }^{71}$

Another point relates to copyright law's requirement of originality. For copyright to subsist in a dramatic work, the law requires that the work be original. This, as noted, is a requirement in derivative works as well. Copyright law does not stipulate what is meant by original. ${ }^{72}$ Israeli courts interpreted originality to mean that the work emanates from the author, and with regards to derivative works, that nominal creativity was invested in the

70 Copyright Act, 5768-2007, 2119 LSI 38 (2007) (Isr.), § 16. The U.S. Copyright Act defines derivative work as "a work based upon one or more preexisting works ...." 17 U.S.C. §101 (2010). A similar definition is found in British law as well, see LIONEL BENTLY \& BRAD SHERMAN, INTELLECTUAL PROPERTY LAW 98 (3d ed. 2009).

71 It should be noted that it is not clear whether indeed a drag number is a derivative work or two separate independent works: the original song (one) and the dramatic routine (two). The analysis here considers that it is possible that the courts might view a drag number as a derivative work. It should nevertheless be noted, that even if the case is of two different works the principle outlined in this paragraph stays the same. Queens want both exclusivity over the song vis-à-vis other queens and exclusivity for the dramatic aspects, whether this is a derivative work or two separate works.

72 TAMIR AFORI, THE COPYRIGHT ACT 94 (2012) [Hebrew]. Other legal systems also abstain from defining originality. See Elizabeth F. Judge \& Daniel Gervais, Of Silos And Constellations: Comparing Notions of Originality in Copyright Law, 27 CARDOZO ARTS \& ENT. L.J. 375 (2009) (US law); Bently \& Sherman, supra note 70, at 93-94 (UK law); Abraham Drassinower, Sweat of the Brow, Creativity, and Authorship: On Originality in Canadian Copyright Law, 1 U. OTTAWA L. \& TeCH. J. 105 (2003) (Canadian law). 


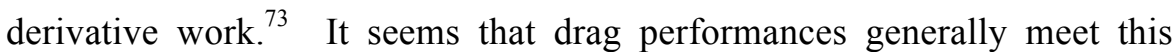
criterion. Nevertheless, most interviewees doubted that the law might view their creation as original, due to the use of others' songs.

Interestingly, almost all interviewees were under the assumption that because they perform to the sounds of copyrighted materials they do not and cannot enjoy legal copyright protection whatsoever. One interviewee phrased this assumption, stating, "You do not protect someone against theft, if he himself stole the property to begin with." In this regard, it is worth mentioning that queens and venue owners claim to be very meticulous about paying royalties to ACUM, the Israeli collective rights society, which also represents foreign collective rights societies regarding use of their works in Israel. The lack of knowledge and the postulation that their creation inherently cannot be protected by the law leads the queens to disregard the possibility that they may be entitled to some copyright protection.

Parenthetically, it is interesting to note the reaction of the original artists to their songs being performed by the queens. It surfaced that by and large the original artists are either indifferent or, in many cases, positive in their reaction to the use of their creations by the queens. For example, Yardena Arazi, a famous Israeli singer, who is one of the senior queens' "signature" singer, has even stated in a newspaper interview that she was inspired to produce a remix of a 1980s hit of hers after watching that senior queen perform to the sounds of her song in the 2006 Jerusalem Gay Pride. ${ }^{74}$ To the best of my knowledge, there was not a single case in which a demand to refrain from performing a certain song/singer was made. Moreover, the year 2013 saw the introduction of "artist tribute shows"-a night in which an original artist is invited to sit as the guest of honor in a drag show dedicated solely to her songs. Often the original artist will join the queens on stage for some of the acts. Many such nights have been performed. Additionally, some famous artists embrace the queens and even engage in creative cooperation with them. For example, in 2014 two dominant Israeli singers - Margalit Tzan'ani ("Margol") and Zehava Ben, produced a song called "Elem Hamudot" (A Fine Young Man). In the song's official music video drag queens portray the two singers, and the singers portray drag queens. ${ }^{75}$

73 "Nominal creativity— to distinguish from mere labor." See Afori, supra note 72 at 98 (Israeli law).

74 See Raz Shechnik, Die, Those Who Envy, Yedioth Ahronoth (Jul. 20. 2012) [Hebrew]. Perzanowski points out, that in the tattoo domain, big corporations (like Disney) whose IP is being used by the tattoo artists (like Mickey Mouse) forgo enforcement efforts. However, unlike the drag domain, he is skeptical of such corporations actually embracing the tattoo industry. See, supra note 3, at 565.

75 The music video was posted by Tzan'ani to her YouTube channel: https://www.youtube.com/ watch? $=0 \mathrm{~g} \_$pflHQ8rE (last visited Jan. 12, 2015); see also Assaf Nevo, Margol and Zehava Ben Celebrate Purim with 'Holy Wigs', MAKO (Mar. 3, 2014) http://www.mako.co.il/music-news/local- 


\section{Fixation and the Protection of Ideas}

Another basic requirement in copyright law for a dramatic work to receive protection is for it to be fixed in a tangible medium. ${ }^{76}$ Drag shows consist of numbers and of stand-up segments in the intervals between the numbers. While the numbers themselves are prepared in advance, and thus, may be recorded (and, accordingly, fixed) beforehand, the stand-up segments are almost entirely dependent on audience interaction. Hence, the stand-up segments cannot be fixed before the show. Most of the shows are indeed recorded; however, a substantial amount is not. But the fixation requirement is not in itself a significant obstacle to copyright protection for drag shows. A queen may easily ask someone from the audience to record the show (a common practicality). Moreover, some Israeli case law opines that a performance in front of a crowd can be deemed as fixation. ${ }^{77}$ The bigger obstacle in this regard is the purpose behind the fixation requirement.

The fixation requirement in copyright law is meant to help distinguish between an idea and an expression. ${ }^{78}$ Although the latter can be copyrighted, the former cannot. ${ }^{79}$ In the drag domain there is no such distinction. Queens can be the owners of ideas, including intangible property such as signature singers, and not merely the expression thereof. When queens speak of stealing a number, they do not mean copying their moves and costumes one to one, but rather copying their idea. For example, if a queen performs Madonna's Like a Virgin in a nun's costume, the drag norms prohibit another queen from performing with the same concept, even if her moves, wig, and costume are totally different. ${ }^{80}$ Under the realm of copyright law, this would be allowed as the concept of a nun

taverna/Article-4e60d9fbf888441006.htm [Hebrew]. Sometime afterwards Tzan'ani cooperated with another drag performer to produce another music video for her song "Po Zeh Lo Airopa" (It Isn't Europe Here): https://www.youtube.com/watch?v=OFZmcSVHnxs\&list=PLU_Hv2jE4FuqCMvZDW bIgIji6JccS8TES (last visited Jan. 12, 2015). Two years earlier, in 2012, the Israeli duo The Young Professionals cooperated with a drag queen for the music video for their song D.I.S.C.O., https:// www.youtube.com/watch?v=VcZnRz7WujA (last visited Jan. 12, 2015).

76 Copyright Act, 5768-2007, 2119 LSI 38 (2007) (Isr.), § 4(a)(1); 17 U.S.C. §102(a) (1990) (U.S.); Copyright, Designs and Patents Act 1988, c. 3(2) (U.K.).

77 This was the opinion of the Jerusalem District Court in CA (Jer) 8303/06 Mechola Dance Ctr. Ltd. v. Cohen, (14.8.2008) (Isr.) (finding that the fact that a choreographic routine was performed in front of an audience satisfies the fixation requirement).

78 See supra note 65; see also the Central District Court's decision in CA (CT) 4130-10-07 Tal v. The Open University, (Isr.). In Tal, a university professor sued the university in which she was working for infringing her copyright in a "pedagogical model" for students in their fourth year at the university. The court held that the model was a mere idea and that copyrights cannot subsist in an idea, ruling in favor of the university.

79 See supra note 65.

80 Specifically, both Madonna's song and the concept of a nun performing a song relating to virginity are, to my understanding from interviewees, in the public domain. 
performing to a song about virginity, even the same song, is merely an idea. ${ }^{81}$ This last example perhaps exemplifies another problem with the fixation requirement. ${ }^{82}$ Some subject matter that is protected under the drag norm system cannot be fixed nor be at all subject to copyright, such as signature songs, signature singers, and personas.

\section{Practical Obstacles that Discourage the Use of IP Laws}

Aside from the doctrinal obstacles, applying copyright law to the drag domain meets practical obstacles as well. The study revealed that the queens' distrust in the aptitude of the legal process to deal with their claims and the assumed cost of litigation discourage them from considering legal resolution. Many interviewees mentioned that they do not believe that the legal system is equipped to handle drag IP cases. ${ }^{83}$ Moreover, as mentioned above, many interviewees stated that they do not believe that they would enjoy copyright from the outset because they use copyrighted materials for their performances. It should be noted that this opinion was voiced despite the fact that many of the interviewees, as mentioned, strictly maintained that they duly pay royalties to the Israeli collective rights society.

Another practical deterrent is the cost of a lawsuit. Although Israeli Copyright Law affords up to N.I.S. 100,000, which is equivalent of approximately 28,000 U.S. dollars in statutory damages, and the courts have full discretion to order recompense of legal fees, interviewees presumed that the litigation costs are high and infringement hard to prove. Interviewees mentioned that no queen has the funds needed to bring a case to court and that it is not worth the trouble vis-à-vis the potential damages, which they usually estimated as approximately a few hundred N.I.S. (a few tens of U.S. dollars). ${ }^{84}$

81 Of course, in copyright law, in cases in which a subsequent work is substantially similar to another, the question of whether the subsequent work is a different expression of a similar idea or the same expression with minor changes may arise. See, e.g., Nichols v. Universal Pictures Corp., 45 F.2d 119, 7 U.S.P.Q. (BNA) 84 (2d Cir. 1930) (holding that at some point, an idea might become detailed enough to constitute expression.)

82 Sprigman \& Oliar present a similar observation in the stand-up comedy domain. According to their findings ideas in the stand-up comedy domain are protected subject matter, even if these ideas are very abstract. The important part in jokes, they observe, is the idea (namely, the "punch line") rather than a specific way to express it. Hence, the idea/expression dichotomy, were it to be applied, leaves stand-up creators with little protection in practice. See Sprigman \& Oliar, supra note 3, at 1802.

83 It should be noted that the interviewees did not express skepticism in the legal system in general. They only observed that in their view it was not adequately equipped to handle drag disputes. This, interestingly, is contrary to findings in other counterculture extra-legal domains. For example, Perzanowski observes with regards to the tattoo domain "[a]s a community, tattooers share a deep scepticism of the legal system." However, their attitude toward law "is best described as indifferent as a matter of day-to-day practice." See Perzanowski, supra note 3, at 567-68.

84 This, of course, is not entirely a correct assumption. It should be noted that the interviewees assumed that the maximum sums they could win as damages from a (theoretical) lawsuit amount to no more than a few hundred N.I.S. Similarly, Sprigman and Oliar point out that in the stand-up domain the 


\section{A. Other Irrelevant Intellectual Property Rights-The Right of Publicity}

The right of publicity is a property-like right of an individual to control the commercial use of her image, name, identity, or other personal characteristics. However, this right is not a part of statutory law in Israel, in contrast to other jurisdictions such as some U.S. States. ${ }^{85}$ The right of publicity was established in Israel by case law, ${ }^{86}$ most notably in the Supreme Court's seminal decision regarding the image of Ariel McDonald, a famous basketball player who sued McDonald's for using his name in a television ad after he had appeared in a television ad for Burger King. ${ }^{87}$ The right of publicity is widely interpreted to include not only the most notable characteristics of a person, i.e., her image or name, but also additional distinctive features by which she can be identified. Accordingly, it appears that queens may indeed have a cause of action if their drag name or persona is being used by another queen. However, it is very doubtfuland no case law indeed supports such an assertion- that the courts will go as far as interpreting the right to include protection to a fictional stage character. Moreover, it seems hard to suggest that even if the right was to be interpreted to include drag personas, it extends to the protection of generic non-physical characteristics harvested from the public domain. Assuming that the right indeed extends to include fictional stage characters, if a queen called "Mariah Jollygoodfellow" whose persona is that of a lonely heartbroken teenager encounters a rival who appropriated her name, character, and appearance as "Mariah Jollybadfellow" whose persona is also that of a lonely heartbroken teenager - then Jollygoodfellow may possibly exercise the right of publicity against the use of the name. However, it is very unlikely that a court will afford any protection against the use of the lonely heartbroken teenager character. The Pessya Girls case is a good example for this point - the arbitrator prohibited Cohen from using the drag names of Hassida and Gladis, but Cohen could still use their characteristics. This is exactly what Cohen did creating two new drag

cost of a law suit was perceived by the comedians as greater than the expected return. Sprigman \& Oliar, supra note 3 , at 1800

85 See Tamar Gidron, The Publicity Right in Israel: an Example of Mixed Origins, Values, Rules, Interests and Branches of Law, 405 STELL. L.R. 405 (2007) (in the Israeli context); J. THOMAS MCCARThy, The Rights Of Publicity And PRivacy $\S \S 6: 1,6: 3$ (2014 ed.); Jennifer E. Rothman, Copyright Preemption and the Right of Publicity, 36 U.C. DAVIS L. REV. 199, 202-203 n.9 (2002) (with regards to the United States); PERSONALITY RIGHTS IN EUROPEAN TORT LAW (Gert Brüggemeier et al. eds., 2010) (in the European Context); Amy M. Conroy, Protecting Your Personality Rights in Canada: A Matter of Property or Privacy?, 1 WeST. J. LEGAL STUD. (2012) (with regards to Canada).

86 Gidron, supra note 85.

87 CC 8483/02 McDonald v. McDonald (Aloniel) Ltd. 58(4) ILR 314 [2004] (Isr.) (holding that according to the Israeli Unjust Enrichment Law there is a right of publicity, but that in the particular case the claimant's right was not breached). 
personas that had the exact same characteristics, only different names. Even if we were to assume that the right of publicity is a relevant cause of action in cases involving the appropriation of a drag name, it is seemingly irrelevant to other persona-related subject matters in the drag domain. Given that the rarity of the scenario in which a name is appropriated, the right of publicity has little to offer queens in terms of their IP protection.

Copyright law has a "one size fits all" structure. ${ }^{88}$ However, this one size does not fit the drag domain - in the cases in which it possibly affords protection, that protection covers only a limited part of the drag subject matter. On top of these doctrinal barriers, queens do not believe that their intellectual creativity is protected by IP laws. This leads to IP law having almost no relevance in the drag domain. To compensate itself for the lack of legal protection, the drag domain, like other extra-legal domains, ${ }^{89}$ has developed social norms that regulate it.

\section{PART III-DRAG QUEENS’ IP NORMS}

In Order Without Law, Robert Ellickson identifies, inter alia, that some social norms are self-enforced while others are enforced by the social group. $^{90}$ In the drag domain these two-self-enforced norms and social group-enforced norms - are clearly visible. What is interesting in the drag domain is that social enforcement is not limited only to the authors; it extends to a second circle, composed of members of a wider social community, who partake in the social enforcement. This, as mentioned, is what I call the correlated social norms. The main, best developed, and most notable IP norms in the drag domain are norms against appropriation. However, interviewees also deemed norms regarding attribution as very significant. Another observation is that many of the norms are directed at preventing appropriation to begin with, rather than enforcing sanctions $a$ posteriori.

\section{A. Norms against Appropriation}

One interesting finding is the rarity of appropriation in the drag domain. Almost all interviewees emphasized that such misconduct is rare.

88 See Graeme B. Dinwoodie, Remarks: "One Size Fits All” Consolidation and Difference in Intellectual Property Law, in The Structure of Intellectual Property Law: CAN One Size Fit ALL? 3 (Annette Kur \& Vytautas Mizaras, eds., 2011).

89 See Sprigman \& Oliar, supra note 3.

90 Ellickson, supra note 39, at 123-36. Ellickson explains: "A person who has "internalized" a social norm is by definition committed to self-enforcement of a rule of the informal control system." Id. at 132. The social group (e.g., other authors in a creative domain) will enforce the relevant rules when a member of the social group disobeys the group's rules (i.e., she has not internalized the rule of the informal control system). 
[Vol. 10:133

This can be attributed to the structure of the drag domain, which is consisted of a socially close-knit and professionally interdependent group, and to the uniquely tailored prevention mechanisms.

\section{A (I). Code of Conduct / "Gentlewomen's Understandings"}

Though by all means informal, all interviewees mentioned that there is a clear code of conduct that is strictly obeyed. Some interviewees referred to this code as a "gentlewomen's understanding." This code is a set of unwritten norms that regulate not only the prohibition on appropriation, but also the terms and conditions regulating the use of a fellow queen's property. The stringency of the norms depends on the status of the subject matter - the more "core" the subject matter, the stronger the norm against appropriating it is, and, accordingly, the stronger the enforcement and sanctions are. The code of conduct, or the "drag commandments," as one interviewee comically called it, includes the following norms: (1) Never copy a persona or a name-This is the biggest "no-no" in the drag world. The prohibition here is absolute, without any derogation. A queen's unique drag character and drag name are her most important IP assets, as one interviewee phrased it: "stealing a song is a transgression, stealing a [signature] song is a crime, but stealing a persona is unforgivable." (2) Never copy a number - A queen's number should not be copied under any circumstances, even if a long period has passed since she last performed it. In the words of one interviewee: "you never [copy a number], if someone copies my numbers, then this is war, I will bury the copycat alive." (3) Never use a signature song or signature singer (unless permitted) Signature songs and singers are the property of the relevant queen. However, the norms allow for using signature songs or singers if the owner permits the use. The owner's permission is at her sole discretion. Some are known to be generous with their signature property, while others are notorious for their obstinacy. Even when permission is granted, the grantee must eliminate any characteristics of the owner's number(s), i.e., the grantee can perform to the sounds of the song but cannot imitate the owner's performance. Many times the permission will be subject to terms and conditions such as it being performed only in specific venues. Another obligation, even if not explicitly mentioned as a condition, is paying attribution to the owner. (4) Refraining from using (non-signature) songsThough not as rigid as the rule regarding signature songs, the code dictates that queens refrain from using a song without prior notice to the owner. This allows the owner to object to the use of the song; if no objection is made, then the queen can assume she may proceed and perform to its sounds. However, if another queen performs to the sounds of other versions or covers of a song, or even to the sounds of the same version belonging to another, the dress, the choreography and pantomime must be 
clearly distinct. It is worth noting that queens will occasionally perform a "tribute show" to one of their fellow queens wherein the use of all her property is completely permitted without any reservation.

\section{A (II). Prevention}

A substantial part of the norms against appropriation relies on ex ante prevention, rather than ex post detection and enforcement. The special features of the drag domain allow for many of these prevention mechanisms to function properly. As mentioned, appropriation is rare in the Israeli drag domain. The prevention mechanisms complement the code of conduct well. There are several types of prevention mechanisms - mechanisms that build on physical and conceptual delimitation; mechanisms that rely on the social characteristics of the drag domain; and mechanisms that promise that other queens have sufficient creative leeway to create without the need to appropriate. While the first two aim at impeding appropriation, the latter is aimed at ensuring that queens do not find themselves left with no alternative but to copy from fellow queens.

The first mode of prevention relies on delimitation. Very much like real-life queens, each drag queen has her own reign, her "territory." The territory spans across three dimensions: geographic, genre, and venue. A queen's territory may include some or all of the three dimensions (e.g., a queen may own a specific venue in a specific city but may not own a specific genre). Some reigns overlap, and two individual queens may have joint-ownership of a territory, genre and venue, they may also share only part of the above. For example, two queens from the town of Beer-Sheva may be the owners of the right to perform Arabic-themed drag (genre) in their town (geographic), but each controls a certain club and is barred from performing in her peer's club; while another queen from Tel-Aviv is barred from performing in Beer-Sheva entirely. Many interviewees have pointed out that since 2010 geographical delimitation has been substantially subsided. This can be traced to: (1) the decay of the drag scene in Jerusalem (which in its glory days out-shadowed Tel-Aviv); (2) the growing popularity of, and demand for, drag shows amongst the general (non-gay) public; and (3) the abandonment of some venues by senior queens. Nevertheless, interviewees stressed that delimitation is still an evident IP protection mechanism in the drag domain with regard to venues. Geographic divide usually follows the national constituencies. Especially in the smaller towns there are queens who control a territory. A new local queen does not need permission to join the territory (though this does not necessarily mean permission to join the genre or venue), but a queen from the outside does. From time to time, queens might invite peers from other territories to perform at the hostess' territory as "special guests." As most of the drag scene now takes place in Tel-Aviv, there has been a shift from a 
rigid territorial divide to a lenient one. Genre divide-Genre means the kind of drag show. This is the least followed and least important divide, and only very few queens enjoy exclusivity of a genre. Examples of genres that are owned by specific queens include: avant-garde drag, Arabicthemed drag, and gender blend drag (a male appearing as a female but deliberately keeping some male appearances, such as a mustache). The venue divide is the most important and followed divide. Queens control certain venues, and others may not trespass their territory. The venues include specific gay clubs and the gay parades in the major cities, etc. As with the geographic divide, owners of a certain venue may occasionally invite other queens to perform there, but only as their invited guests. ${ }^{91}$

The second mode of prevention of appropriation builds on the structure of the drag domain. Firstly, the drag community is a small close-knit community, in which all the performers know one another. This means that the social connections function also as a prevention mechanism because one is less likely to appropriate from someone she knows. Secondly, it is extremely hard for a single queen to make it on her own in the drag world, especially a new amateur queen. A queen knows that if she is caught appropriating, she will be sanctioned. This is a significant tool of deterrence. Thirdly, the drag persona acts also as an additional protection layer. The fact that each queen finds her own niche and specializes in it makes it harder for potential copyists to copy or steal from her and makes detection easier as well. ${ }^{92}$

The Third prevention mode aims at eliminating, or minimizing, the need to appropriate from the outset by ensuring a wide enough public domain. This is one of the key figures that assist in preventing a collapse of the drag norm system or a tragedy of the commons. ${ }^{93}$ The queens are very well aware that if there are not enough materials left for others to be able to perform relatively easily, then appropriation and stealing will unavoidably become commonplace. Therefore, there is a plethora of what the queens call "slut numbers," "slut singers," and "slut songs" to which no queen can claim ownership, even if she was the first (and only) to perform them. For

91 One of the interviewees mentioned a story regarding a bitter "war" that started when an established queen started a talk show style performance in the Evitta club, one of the central gay venues in Tel-Aviv, without the consent of two senior queens who "own" the club and who have a weekly drag show there. The established queen was soon exiled from the club, and only after long negotiations, in which she undertook to refrain from putting on any drag shows and only using her drag persona as a hostess, was she allowed to re-establish her "talk show."

92 Similar observations have been made in other extra-legal domains. Sprigman and Oliar, for example, assert that stand-up comedians "personalize" their performance, which makes copying harder and detection easier. See Sprigman \& Oliar, supra note 3, at 1855-1856.

93 The "tragedy of the commons" refers to a theory by Garrett Hardin, according to which individuals, who act independently and rationally according their personal self-interest, behave contrary to the long-term best interests of the whole group by depleting a common resource. Garrett Hardin, The Tragedy of the Commons, 162 SCI. 1243 (1968). 
example, the songs and features of Madonna and Barbra Streisand, and any numbers performed using their creations are in the public domain. This factor is of special interest, as it goes against what seems like the natural instinct - to gain control of as much of the subject matter as possible. However, the queens, and particularly the senior ones, apparently understand that their fellow peers must have a sufficient amount of materials to work with. As one of the interviewees observed: "[a certain senior queen] has been performing for over twenty years, I don't think there is a song she hasn't performed. If it all belonged to her there would either be just one drag queen in Israel or that 'jungle rules' would prevail." This, seemingly, is yet another spontaneous manifestation of John Locke's "proviso.",

This feature - of the creators ensuring a wide enough public domain, is unique to the drag domain vis-à-vis other extra-legal domains. It seems that three conjoined reasons best explain why it is that drag queens, and no other extra-legal community of creators, have such a strong notion of a wide enough public domain: (1) The size of the Israeli drag domain-As mentioned, the Israeli drag domain, is a relatively small and close-knit community. In such a small community, it is fairly easy to balance between the private and the public domains and make sure that enough and as good is left for both. This, ostensibly, is harder to do in a larger domain. (2) The value of the public domain-As mentioned, without a wide enough public domain the drag industry is at risk of "jungle rules" prevailing, risking the existing private domain and the drag industry at large. The queens care for, and love, the drag "institution" and are willing to give up some potential property for its sake, even if personally, they will not be affected. For them, the price is worth the gain. (3) The unique subject matter-Some singers, such as Madonna, Barbara Streisand and Dana International, are gay icons, and perhaps even inspirational figures. Likewise, some songs such as I will survive, Over the Rainbow, or Girls Just Want to Have Fun are gay anthems. Harvesting these from the public domain is deemed as clearly unfair. The fact that other extra-legal domains do not share this kind of subject matter and social environment is yet another possible reason why only the drag domain has developed this unique feature.

\section{A (III). Enforcement}

Naturally, the first stage of enforcement is detection of appropriation. In the intra-legal domains this is usually done by the copyright holder or her agent, and, in some of the other extra-legal domains, by the creator or the community of creators (and possibly also the users/consumers of the

94 See supra note 67. 
[Vol. 10:133

domain). ${ }^{95}$ In the drag domain, detection heavily rests on people other than the owners or their direct agents. The first detecting mechanism is peerbased detection. Much of the detection is done by the senior queens, who host most of the drag shows and are well acquainted with the different ownerships. In addition, drag queens many times come to watch their friends' shows (usually as a friendly and supportive act, not as an act of monitoring) ${ }^{96}$ A queen who witnesses another queen performing materials that are suspected to be subject to the ownership of a third queen will many times report the appropriation to the owner. The motivation to report can be traced to both maintaining the social order (displaying fury towards the queen who broke the code) and a reciprocity motive (I will inform you today, you will inform me tomorrow).

Another detection mechanism is audience-based. This category divides into two sub-categories: related services providers' detection, and viewers' detection. Related services providers are club owners, D.J.'s, bartenders, and photographers. They are present in many of the events that take place and are usually aware of ownership of certain numbers and signature songs/singers. They tend to inform the owners if they witness appropriation. The motivation to inform the owners is usually explained on moral grounds. One interviewee (who is a D.J. and a club owner but is not a queen) described: "stealing another's number is violence on the stage. Not only will I not allow a thief on my premises, I want the owner to be able to settle her account with the thief." The second audience based detection mechanism is viewers' detection, i.e., people who come to watch the show notice the appropriation. The motivation for such detection was described in two ways: first, the viewers feel that a queen who does not make an effort to be original disrespects them, and they want her to be punished. The viewers, it should be noted, pay between twenty N.I.S. to one-hundred N.I.S. (ranging from about six to twenty-eight U.S. dollars), and, according to the queens' testimonies themselves, they expect the queens to respect them by delivering an original show. ${ }^{97}$ The second reason is, as one interviewee put it: "not out the goodness of their heart but because gays love nothing more than a cat fight."

In cases in which the appropriator is not punished on-stage on the spot, before turning to sanctioning the appropriator, the owners will usually confront her and demand an explanation. ${ }^{98}$ Many cases of appropriation are

95 See, e.g., Sprigman \& Oliar, supra note 3, at 1813; Perzanowski, supra note 3, at 550.

96 A similar phenomenon in the stand-up comedy domain is described by Sprigman \& Oliar, supra note 3 , at 1813 .

$97 \quad$ See La Rue, infra note 108.

98 See, similarly, Sprigman \& Oliar, supra note 3, at 1814, who observe that in the stand-up comedy domain confrontation is usually the initial step before actual sanctioning; Perzanowski, supra note 3 , at 550-51, observes similar behaviour in the graffiti domain. 
resolved in an amicable manner. If the owner is satisfied, then that will usually be the end of it; though most times, some form of symbolic punishment or at least public apology will still be applied, mainly for deterrence reasons, i.e., reclaiming the owner's ownership and sending a message to other potential appropriators. For example, the appropriator will be required to perform a tribute to the owner in her next show, or the appropriator must upload the owner's original version to her own social network page. Nevertheless, in some cases, usually those of extreme misconduct, there may be punishment without prior confrontation.

Appropriators are socially sanctioned, though the need to revert to sanctions is relatively uncommon since the drag code as well as the prevention mechanisms evidently succeed in preventing appropriation. Nevertheless, a robust and very efficient enforcement mechanism exists. There are two kinds of enforcement mechanisms: the first is practiced amongst the queens themselves, what we might call intra-communal sanctions. The second relies on the different users of the drag domain, what can be categorized as correlated-communal sanctions. Naturally, the more severe the appropriation, the stronger the sanction. Thus, for example, appropriation of a non-signature song will lead to a one-time low-scale punishment, while appropriating a drag-persona may very well result in the strongest form of punishment for an indefinite duration. Drag queens, unlike the creators in some of the other extra-legal domains, never revert to physical violence. ${ }^{99}$ The choice of which sanction to execute is at the discretion of the owner, and oftentimes more than one method of punishment is used. Most interviewees agreed that the queens are proportionate in their enforcement. Intra-communal sanctions include three retaliation options (in ascending severity order): public on-stage shaming, badmouthing and gossip, and boycotts and professional isolation.

Public on-stage shaming - The most widespread of all intra-communal sanctions is shaming the appropriator in front of a crowd. Namely, mocking her before her audience. Such public shaming will dampen the appropriator's public image. A queen's reputation, in the eyes of her audience, is her most important asset. ${ }^{100}$ Given the importance of the social reward of recognition to drag queens, and their sensitivity to their reputation, public shaming is an effective punishment. ${ }^{101}$ This punishment is

99 See, e.g., Fagundes, supra note 3, at 1109 (in the roller-derby domain); Sprigman \& Oliar, supra note 3, at 1797 (in the stand-up domain); Roundtree, supra note 3, at 983-985 (in the graffiti domain). Ellickson also describes acts of violence taken by the residents of Shasta County as part of "self-help retaliation," supra note 39, at 57-59.

100 See La Rue, infra note 108, at 233-34. Audience's appreciation, though not necessarily the most important asset is indicated in other extra-legal domains. See, e.g., Sprigman \& Oliar, supra note 3 , at 1816 (regarding stand-up comedy).

101 Underwood, writing about the famous drag queen Danny La Rue, indicates (already in 1974) a similar observation: "In talking with a number of drag artists I found, as other writers have found, that 
usually executed by the hostess of the show in which the appropriator performed since on-the-spot punishment provides a more glaring and strong effect. ${ }^{102}$ As one interviewee observed: "[if you are caught copying] the host-queen will crucify you on stage on the spot." Some interviewees suggested that the host queens execute this punishment not merely for the sake of comradeship, but also (and mainly) to reinstate the drag code, or for the sake of demonstrating to their audience that they respect them by prohibiting appropriation on their stage. The punishment may also be a delayed punishment executed by the owner herself at a later time. This is usually the case when the host queen is unaware of the appropriation or unwilling to punish the appropriator immediately. In such a case, the owner will usually badmouth the appropriator on stage on her next performance and then perform the stolen number to demonstrate "how it should really be done," reinstating her ownership. ${ }^{103}$

Badmouthing (offstage) and gossip-Another intra-communal punishment method is badmouthing the appropriator amongst the other queens. A queen's reputation is important to her not only in front of her crowd but also, to a significant degree, within the drag community. ${ }^{104}$ The drag community is a close-knit group; it is not just a professional guild but also a social club, and one's standing in it is of importance. A tarnished reputation is not only a barrier to career success; it is also a barrier to social acceptance and may lead to social isolation. ${ }^{105}$

some female impersonators are extraordinarily sensitive to criticism and will go to considerable lengths to avoid any kind of ridicule or disrespect." Underwood, supra note 5, at 20.

102 This form of punishment is to a great degree unique to the drag domain and rarely found in other extra (or intra) legal domains. Possible reasons might be the familiarity in the drag domain (easy detection - queens know what belongs to who, so they need not double-check with the owner), and the fact that the punishment is executed within the gay community (thus they do not face the dilemma of airing grievances in front of "strangers", since the gay community is perceived as family, not strangers). However, though rare, some cases of public on stage shaming have been observed in other extra-legal domains. Sprigman \& Oliar, supra note 3, at 1821-22, give the example of a public on stage shaming executed by the comedian Joe Rogan who chose to end his stand-up act by insulting Carlos Mencia, a peer who was sitting in the audience who Rogan accused of joke-stealing. It is interesting to note that Sprigman \& Oliar observe that the stand-up community was split between those who viewed Rogan's acts positively and those who viewed it as an unwanted public airing of grievances.

103 It should be noted that public shaming on the stage is not reserved exclusively for public punishments. Stage mockery can also be the result of pure envy or as a mechanism to insure and reinstate the drag hierarchy. I have personally witnessed a performance by a new queen who was exceptionally good; the host (a senior queen) mocked her appearance saying, "who's done your makeup, love? Stevie Wonder? You look like a common hoochie. Next time stop over at my place. I'll give you some makeup tips." To my question, another queen that was in the crowd explained that the performer has done nothing wrong, however the senior queen had to place her in her right place in the hierarchy.

104 The importance of reputation within the creative community cannot be overstated, and is predominant in most, if not all, other extra (and intra) legal domains. See, e.g., Fagundes, supra note 3, at 1127 (regarding roller derby pseudonyms); Fauchart \& Von Hippel, supra note 3, at 187 (regarding high cuisine); Roundtree, supra note 3, at 983 (regarding graffiti); Sprigman \& Oliar, supra note 3, at 1815 (regarding stand-up comedy).

105 This observation, seemingly, is valid across all extra-legal domains. Gossip and bad- 
Boycotts and professional isolation-Ostracism, boycotts, banishing and professional isolation can be a consequence of badmouthing, but interviewees pointed out that these will almost always be implemented only when explicitly sought for and not as a "natural" consequence of badmouthing. Reserved for cases of the worst misconduct such as persona appropriation the boycott/professional isolation scale spans from prohibition on lending costumes, via refraining from inviting the appropriator to appear on stage, up to refraining from cooperation with queens who associate with the appropriator. The boycott is complete and almost all queens (and, as will be seen, also related services providers) obey it. ${ }^{106}$ One interviewee, reflecting on the general notion, observed: "A copycat's worst sanction is being isolated, it's an industry that created itself as one in which you cannot act alone, without mutual support you've got a big, big problem. You're done." Interestingly, almost all of the interviewees mentioned a notable specific case of a "baby" drag, a rising star that was the protégée of two of the most senior queens and was, according to the interviewees, "one of the greatest promises of the industry." This "baby" drag appropriated the persona and signature songs of her two "mother" drags when the latter were on a show tour abroad. She used her access to their clothes and costumes, and appeared as the celebrated divas themselves. The case was reported to the mother drags who banished their protégée from the drag community for life. Now, several years later, the appropriator is still banned from the stage and the drag community. The drag mothers will also avoid cooperation with a third queen that proposes to work with the appropriator. To my inquiry regarding a possible pardon to the prodigal daughter, one of the interviewees replied "not in a million years. She has done the unspeakable. Stealing from your mothers! [One of the mothers] still shudders in rage when she hears her name." To my question: "but do you forgive her?" he replied, "it's not up to me."

As previously discussed, the sanctions are not the calling of the owner only, but executed by the community of queens as a whole; though the decision as to the form of punishment is at the discretion of the owner. Interviewees agreed that the community will always follow suit unless there is a feeling of a personal vendetta (though no one could remember such a

mouthing amongst the cadres of creators is an important and effective enforcement method in many different extra-legal domains. See, e.g., Perzanowski supra note 3, at 550; Fauchart \& Von Hippel supra note 3, at 187; Roundtree supra note 3, at 983-984; Sprigman \& Oliar supra note 3, at 1815, 1817.

106 Bendor and Swistak contend that in order for a social norm system to function and remain stable, the obligation to impose punishment cannot be restricted to those hurt by the transgression, but it must be extended to third parties. This is ostensibly the case in the drag domain. Moreover, it seems that punishing queens who not do not participate in enforcing the norm system signals that this is not an optout-at-will system, thus it is also an important factor in keeping the drag norm system stable. See Jonathan Bendor \& Piotr Swistak, The Evolution of Norms 106 Am. J. Soc. 1493 (2001). 
case) or a disproportionate punishment (again, no one could think of such a case). Another interesting point in this regard is that in cases in which the so-called appropriator argues that she was wrongly accused (on the grounds that the number was in the public domain, etc.) a more senior queen will function as an arbitrator or a mediator. One of the senior queens testified to an interesting case of inner-adjudication: she and another senior queen were approached by a third senior queen that claimed that a fourth senior queen stole a signature song belonging to her. The accused held that the song was in the public domain. The accuser testified that it was not a well-known popular song, but rather that she found the song after hard work of "hunting" songs in a record-shop. The adjudicators accepted the accuser's version and barred the appropriator from performing to the sounds of that song. They also notified the owner of the venue in which all four used to perform that she is banned from performing to that specific song's sounds.

Alongside the intra-communal sanctions, sanctions that are executed by others have an important role in the enforcement of the antiappropriation norms. The correlated-communal sanctions complete and enhance the intra-communal ones. The executioners of the correlatedcommunal sanctions, as mentioned, are the users of the drag domain-the related services providers and the viewers. I have already pointed out to the importance of the different audiences in the process of detection; their role as enforcers of the anti-appropriation norms is significant as well.

Related services providers are a significant element in the enforcement of anti-appropriation norms. Services providers do not automatically adhere to punishing appropriation, but they do respect the sanctions when they find them fitting. Their participation in the enforcement executed by way of limiting the appropriator from appearing on their stage can be traced to two main reasons: moral standing and the reciprocal relations with the queens. Many times the related services providers view appropriation as a moral wrongdoing and stealing of a queen's hard labor. An interviewee who is a club owner said: "drag is an art in all respects, and stealing it is stealing in all respects. If someone copies a Picasso I will not put the copy up on the wall in my club, same for drag shows"; or, as another venue owner (who is also a queen) put it: "over my dead body will a thief appear [on my stage], because she stole another girl's property." Apart from the moral standing the reciprocal relations play a part—queens are more likely to cooperate with a related services provider who seemingly cares for their intellectual property. This mirrors an interesting socio-legal nexus-social ordering, designed for the protection of intangible goods (the drag domain's norm system) is supported by the legal ordering of ownership in tangible goods (the services providers' property rights). ${ }^{107}$

107 Sprigman and Oliar make a similar observation in the stand-up comedy domain. They found 
Viewers are mainly gay men that come to see the shows in a recurring manner. They are key to many of the queens' social and financial rewards. The queens derive their social status (outside of the drag community) mainly from the viewers. Additionally, the viewers are the potential pool of ticket purchasers to the queens' shows. A queen's reputation and good relations with the viewers are vital for her. Accordingly, viewers hold a significant destruction potential. While viewers were not interviewed in this study, the queens articulated some reasons for their participation in enforcement mechanisms. One of the interviewees put it simply: "copying from another queen is stupid because you are a fake-you insult your crowd and they won't forgive you. Gays are a very unforgiving crowd." Some interviewees mentioned that the viewers, though by no means a homogeneous group, see themselves as protectors of their "heroes," the queens, and will severely punish those who appropriate from them. However, other interviewees emphasized that this loyalty is very fragile and unreliable. In addition, most interviewees stipulated that viewers expect the performers to perform original shows. ${ }^{108}$ If instead, they get an appropriated show, they will seek to punish the appropriator. ${ }^{109}$

that intermediaries - club owners, booking agents, agents, and managers, sometimes refuse to deal with appropriators or to allow them to perform in their venues. See, Spirman \& Oliar, supra note 3, at 1818. It seems, however, that this is much rarer in the stand-up domain than in the drag domain. A possible explanation can be that the related services providers in the drag domain feel a part of a shared community with the drag queens, and hence feel more obligated in general, and more strongly about appropriation in particular. Another explanation can be economic-in the drag domain a services provider is perhaps more reliant on the creators for economic gain than his peer in the stand-up domain, therefore good standing with the queens is more important.

108 In his autobiography the famous drag queen Danny La Rue makes the following observation regarding the audience-performer relations and the importance of providing the audience with originality: "I have retained my position all the way because I am a product of the people and desperately try to live up to them. The audiences dictate what every performer does in his career. They make demands and we follow. What the public have liked about me is that I have never abused my profession or compromised my talent. I have done everything tastefully. . . . In any business, standards are so important and mine must live up to the faith the public have in me. . . . The public know me and everything I stand for and hopefully they are never disappointed. Professional, if I say my shows will be glamorous, they will be. No expense will be spared to deliver the goods. If you build up a reputation you must try to retain it - the public demand it. But I'm like a village shopkeeper - I always give good service- and when you do that people come back. . . . I loathe unprofessional artists and I'm afraid there are quite a few of them. They have no love for this great business of ours and behave dreadfully. They have tremendous influence through their standing, and yet they let everyone down. The trouble is show-business seems to have lost a lot of its professional attitude in recent years with so any artists taking liberties with their audiences, fobbing them off with any old rubbish, in the name of entertainment, instead of working hard at their trade at all times. . . Artists should never take their success or their audience for granted and should always strive to better themselves. It's a hard life and needs lots of dedication and discipline." DANNY LA RUE, FrOM DRAGS TO RICHES 233-34 (1987) (emphasis in original).

109 It is interesting to note, that this phenomenon is not exclusive to the drag domain, though it seems that only in the drag domain this phenomenon is as strong and as vivid. For example, Sprigman and Oliar indicated that their interviewees in the stand-up domain were split on the question of whether 
Interestingly, this applies to self-plagiarism as well; for example, using the same moves, dress, wig and make-up for different songs. ${ }^{110}$ One interviewee phrased the above understanding thus: "people value originality and want to be stimulated, if you steal from another or even from yourself, you will lose them in a flash." The main way in which the viewers partake in the enforcement mechanism is badmouthing and gossip. The viewers are a relatively closely related and small group, and once the word about an appropriation gets out, the appropriator is quickly defamed. It will take a defamed queen a substantial amount of time and labor to reclaim her reputation.

One can rightly assert that even in a well-structured enforcement system, there are cracks and lacunas through which some lawbreakers might get away. However, the interviewees all insisted that while this assertion is valid, they cannot recall any case in which the system failed. The interviewees explicitly dismissed the possibility that the sanctions do not affect the most senior queens who can allegedly get away with appropriation if they appropriate from less-senior queens. One of the many similar responses to such an assertion was that "they are the biggest beneficiaries of the code of conduct, they own most of the [signature] songs, they will never risk [jeopardizing] the system or their reputation." However, it seems that there is also a deeper explanation. It surfaced that the senior queens see the drag domain as something that gives them meaning. They will not jeopardize the system, even if they can get away with it, because the system as such is very valuable to them.

With regards to queens on the fringes - queens who are less engaged with the main drag community and are, therefore, less affected by sanctions - the interviewees generally agreed that the social norm system is nevertheless effective, even if to a somewhat lesser extent. One of the interviewees who self-identifies as an "off the mainstream queen," said "we have no desire to perform in [the main gay venues], and while punishment will not mean much to us, we will never copy," even though that he appears only in private parties, and therefore ostensibly less exposed to detection and less effected by sanctions and social isolation. Again, it surfaced that

\footnotetext{
viewers are aficionados who care about originality and non-appropriation. They found that even those interviewees who thought that such aficionados do exist estimated that they add up to approximately ten to twenty percent of the viewers. However, Sprigman and Oliar also found that in the stand-up domain aficionados can be a part of enforcement (by refraining from coming to shows, bad-mouthing appropriators etc.). Sprigman and Oliar hold that the internet may be a catalyst for "comedic vigilantes to enlist the audience in enforcing anti-appropriation norms." See Sprigman and Oliar, supra note 3, at 1824-1825, 1862. In the domain of high cuisine, on the other hand, consumers very much care for originality, as suggested by Fauchart \& Von Hippel, supra note 3, at 194.

110 One interviewee who is a queen and a venue owner mentioned that a certain drag show that was extremely popular in the past has lost a substantial part of its viewers due to recycling and self plagiarism.
} 
the reason for adherence in this case was not the fear of sanctions but rather the significance that the domain conveys for its creators.

These two observations - the adherence of the senior queens and the queens on the fringes can seem at first somewhat counter-intuitive. In fact, many researchers hold, that in norm based systems the very high status members or the very low status members often conform less to the social ordering, as they are less likely to be affected by enforcement. ${ }^{111}$ It seems that the queens' love of, and devotion to, the drag community and the drag scene overcomes their personal narrow interests. Or, in utilitarian terms, they understand that otherwise the drag domain might subside and their gain from its good operation overcomes the potential gain from appropriation. ${ }^{112}$

The interviewees also rejected the possibility of abuse of the enforcement system for personal gains or retribution. There was agreement that, even though some queens badmouth or publicly shame others due to a personal dispute, they will not abuse the system and claim appropriation when that is not the reason for the said actions. Interviewees noted that since the drag community is a close-knit community in which things get out quickly, if a queen is caught abusing the system other queens might refuse to assist her in cases of real need or even punish her.

Two issues relate to the extent of enforcement-the duration of the sanctions and limited or reduced enforcement. As to the duration, there is no strict pattern. By and large, the sanctions are limited in their duration and usually last a relatively short period of time, even to major offences, such as number stealing, no more than a few weeks. Though naturally, reestablishing reputation and trust may take much longer. Except for the one single case in which a queen was effectively banished for life from the community, no sanction lasts for an indefinite period of time. As can be expected, the severity of the offence dictates the duration of the punishment; after a while (usually a few weeks), when there is an impression that the appropriator has been adequately punished, the drag community starts to act in a "business as usual" manner with the appropriator.

There are cases of limited or reduced enforcement. These can be

111 Richard Hackman holds that "[T]here is evidence that group members who do not much need or care about the social rewards which can be provided by their fellows (e.g., very high status members or very low status members not committed to remaining in the group) often conform less than other group members. " Richard Hackman, Group Influences on individuals, in HANDBOOK OF INDUSTRIAL AND ORGANIZATIONAL PSychology 1455, 1506 (Marvin Dunnette, ed., 1990). Eric Posner suggests that "people violate social norms because other people cannot afford to ostracize them." ERIC POSNER, LAW AND SOCIAL NORMS 28 (2000).

112 Other explanations, of course, exist. For example, it can also be argued that senior queens have an embedded interest in keeping the system alive and functioning, for their own personal benefits, e.g., to prevent a new and extremely talented queen from taking over their position. 
[Vol. 10:133

classified into four: where the appropriation was done for a good cause, when the owner forgives the appropriator, when adequate attribution was given, or when appropriation was done as part of a tribute show. First, with regards to good cause cases, interviewees mentioned that there was very lenient enforcement towards copyists who by way of their specific performance promoted the community or the scene; e.g., using a peer's jokes without permission while being interviewed for national television. Second, when the owner of the song forgives the appropriator, naturally, no sanction will be applied or, as mentioned above, just a symbolic one, for deterrence reasons. Thirdly, if a queen did not seek prior permission, and appropriated a number or a signature song/singer, but attribution was explicitly given on stage, usually the owner will forgo punishment. Lastly, as mentioned, once in while some queens will stage a "tribute show" to one of their fellow queens. In such cases the use of any of that queens' property is permitted without reservations.

A (IV). Duration

According to the interviewees there is no clear "code" with regards to the duration of the ownership rights in the drag domain. It is generally agreed that once a queen retires all her numbers and signature songs/ singers automatically return to the public domain. With regards to her drag persona, this too returns to the public domain, but only after a more substantial amount of time has passed. Her drag name, however, remains protected for a seemingly indefinite period of time. ${ }^{113}$ As to still active queens, interviewees generally agreed that the ownership in songs expires after a "long enough" time has passed since they were performed by the owner; however, the exact duration is vague. Some suggested "once people forget who performed the song" as an indicator for the point in time at which the rights expire. Ownership in signature songs/singers subsist with the owner so long that she is active. As to numbers and jokes ownership lasts longer than regular songs but not until retirement. As is with songs, a certain expiry date was not specified, but many interviewees mentioned that usually after time has passed the owner will willfully allow another queen to copy it, and that once two queens or more were given permission, the number becomes part of the public domain. In contrast, the Israeli copyright law accords the owner of a dramatic work with exclusivity over her creation for the whole of her lifetime and another seventy years thereafter. ${ }^{114}$ In

113 One interviewee mentioned a case in which the drag queen named Miss Hypnotic, who was retired for several years, allowed a young queen to use her name on stage. The young queen was booed by some of the older viewers who remembered the "original" Miss Hypnotic and disdained the "new" one for the "theft." The young queen had to apologize to the crowd and explain that she was given prior consent.

114 Copyright Act, 5768-2007, 2119 LSI 38 (2007) (Isr.) § 38. Similar durations are accorded in 
some other extra-legal domains, the duration of time in which the rights subsist in the creator is indefinite, while in others, retired creators' creations return to the public domain. ${ }^{115}$

\section{B. Additional Drag IP Norms}

Drag queens are very sensitive to what they consider to be their intellectual property. The norms against appropriation, as discussed, clearly manifest this understanding. Alongside the anti-appropriation norms, norms regarding attribution, as well as other norms, have a place of importance. These will be discussed below.

\section{B (I). Priority}

In copyright law, priority has little significance. If two authors happen to independently create similar creations at a different time, both may enjoy exclusivity rights over their creation. ${ }^{116}$ According to patent law, however, in order to obtain a patent, one must be the first to file an application for it. ${ }^{117}$ The practice in the drag domain is very similar to that of patent law, with a public performance substituting for the patent registrar. ${ }^{118}$ Once a new song is released (by a non-signature or a "public domain" singer), a race to be the first to perform it begins, and the first queen to publicly perform the song wins the ownership with all that applies.

\section{B (II). Joint Authorship and Transfers}

Many numbers are performed by a duo of queens or even more. These numbers are usually the result of mutual creative labor and, in such a case, are co-owned by all the authors. In this regard, the drag norm and the copyright law are similar. ${ }^{119}$ According to copyright law, the transfer of copyright ownership is possible. ${ }^{120}$ In the drag domain transfer of ownership

most jurisdictions. See, e.g., 17 U.S.C § 302 (1998); Copyright, Designs and Patents Act, 1988, c. 12 (U.K.), amended by Duration of Copyright and Rights in Performances Regulations, 1995 §; Copyright Act, R.S.C., 1985, c. C-42 (Can.) (in Canada the term is fifty years).

115 Sprigman \& Oliar, supra note 3, at 1824, explain that in stand-up the duration is indefinite. Fagundes describes that in the roller-derby domain the names of the skaters return to the public domain after retirement (however, as he describes, this diminishes the skaters' motivation to announce their retirement). See Fagundes, supra note 3, at 1121.

116 Of course, the creator of the latter creation must prove she has not copied from the first creator

117 Patent Act, 5727-1967, 510 LSI 148 (1967) (Isr.) §9.

118 Similar observations have been made with regards to high cuisine, see Fauchart \& Von Hippel, supra note 3, at 194; and stand-up comedy, see Sprigman \& Oliar, supra note 3, at 1826.

119 Copyright Act, 5768-2007, 2119 LSI 38 (2007) (Isr.) § 1; 17 U.S.C. § 201(1978). See Bently \& Sherman, supra note 61 at 125-27, (regarding the U.K.).

120 Copyright Act, 5768-2007, 2119 LSI 38 (2007) (Isr.) § 37; 17 U.S.C. § 204 (1976). See Bently \& Sherman, supra note 70 , at 127-28, (regarding the U.K.). 
in songs is not possible. Once the owner has given a certain queen permission to perform the song it automatically enters the public domain. Yet, with regards to a signature song or a song performed by a signature singer, even if the owner transfers the right to perform to another queen the ownership still subsists with the original owner. However, if a queen allows the use of her signature songs/singer more than once (and a reasonable period of time has not passed), this will be considered as a waiver of ownership and the song/singer will return to the public domain.

\section{B (III). Limitations on Ownership}

Copyright law dictates several exceptions and limitations to ownership. The most notable and open-ended of them is the fair use doctrine. $^{121}$ The fair use doctrine permits limited use of copyrighted materials without seeking prior consent from the right holder in certain cases which are deemed socially desirable, such as parody, news reporting, academic use, etc. In the drag domain, there is no explicit "fair use" rule. However the norm allowing use of a fellow queens' property in cases of "tribute shows" can be deemed as some kind of "fair use" practice. Additionally, as mentioned, there are cases of limited or reduced enforcement in certain circumstances-when appropriation served a "good cause," and when attribution was given. This feature seems unique to the drag domain vis-à-vis other extra legal domains, as will be explored below.

\section{B (IV). Attribution Norms}

In Israeli copyright law, the author of a creation (she is not necessarily the owner) enjoys certain "moral rights." These include the right to attribution, i.e., to be identified as the creator, and the right to object to derogatory treatment of her creation. ${ }^{122}$ In the drag domain, attribution plays a very significant role. All interviewees emphasized the importance of attribution; one interviewee summed it: "credit is the heart of it all." As mentioned, even in cases in which prior permission to use another queen's property is given, attribution is customary. Moreover, proper attribution may very well lead to reduced sanctioning in cases of appropriation. ${ }^{123}$

121 Copyright Act, 5768-2007, 2119 LSI 38 (2007) (Isr.) § 19; 17 U.S.C. § 107 (1992). See Michael Birnhack, Justifying (Israeli) Fair Use (forthcoming) (on file with the author).

122 Copyright Act, 5768-2007, 2119 LSI 38 (2007) (Isr.) § 46. In the U.S., the situation is a little more complex. Moral rights are protected to a limited degree through judicial interpretation of several copyright, trademark, privacy, and defamation statues, and through the Visual Artists Rights Act of 1990 (codified as 17 U.S.C. § 106A (1994)). See also Betsy Rosenblatt, Moral Rights Basics, available at http://cyber.law.harvard.edu/property/library/moralprimer.html (last modified Mar. 1998); ROBERTA Kwall, The Soul of Creativity: Forging a Moral Rights LaW fOR the United States (2010); Thomas F. Cotter, Pragmatism, Economics, and the Droit Moral, 76 N.C. L. REV. 1 (1997); Bently \& Sherman, supra note 61, at 241-60.

123 There is no indication in the studies of other extra-legal domains that attribution will reduce 
While attribution is not enforced, and no sanction lies with a queen who did not give attribution if she was not compelled to give attribution by the owner, refraining from attribution is a "moral sin" and is detested. ${ }^{124}$ Interviewees indicated that it is extremely rare that attribution is not given. As to the right to object to derogatory treatment, it apparently is nonsexist in the drag domain.

The above discussion of the additional drag IP norms sheds light to an interesting and unique feature of the drag domain vis-à-vis other extra-legal domains. This feature is the modularity of its norms: the duration of ownership and the enforcement mechanisms are gradual and respective to the importance of the subject matter or the severity of the misconduct. Additionally, the drag domain has more exceptions and limitations, and possibility of transfers than any other extra-legal domain. ${ }^{125}$ This is in contrast to the trend in other extra-legal domains in which there seem to be relatively narrow rights with uniform enforcement and ownership duration and few or no "defenses" to violation of the ownership rights. Four conjoined reasons seemingly explain this unique feature: (1) The subject matter-As mentioned, in the drag domain there is the widest array of different ownership assets in comparison with other extra-legal domains. Additionally, there is a clear differentiation in the importance of different kinds of subject matter-while some kinds of IP assets are more identity constitutive (such as persona and name) others are less (such as nonsignature songs). Shorter duration, more exceptions, and less rigid enforcement seem a natural consequence of such a structure. By contrast, in other extra-legal domains, as mentioned, the range of the protected subject matter is much more limited, and in some domains, such as roller derby pseudonyms, is entirely identity constitutive. ${ }^{126}$ (2) The size of the community - The Israeli drag domain, as mentioned above, is a small and close-knit community. Its relatively small size allows it to be more flexible

the punishment for appropriation. However, it should be noted that Sprigman and Oliar do hold that in some instances in the stand-up comedy domain if the appropriator provides immediate on-stage attribution, the appropriation might be deemed less acute to a certain extent. See supra note 3, at 18291830 .

124 In comparison, in some other extralegal domains, such as high cuisine and graffiti, attribution plays a similarly significant part; in others, such as stand-up comedy, it has negligible importance (or plays no part at all). See, respectively, Fauchart \& Von Hippel, supra note 3, at 193, 199; Roundtree, supra note 3, at 973, 980; Sprigman \& Oliar, supra note 3, at 1829.

125 To the best of my knowledge only in two other extra-legal domains were any exceptions and limitations identified; and there too, they were very narrow in scope. Sprigman and Oliar, for example, note that in the stand-up comedy domain there is no "fair use" style exception; nevertheless, they do suggest that in cases of immediate on-stage attribution, and in cases of young comedians violating the social norm system, the violation is seen as less acute. See Roundtree, supra note 3, at 1828-30; 1864. Roundtree notes that in the graffiti domain graffiti custom allows some copying of otherwise protected work for the benefit of the community as a whole. See Roundtree, supra note 3, at 980).

126 See Fagundes, supra note 3, at 1098. 
than other bigger extra-legal domains. Naturally, detection of abuse of exceptions is easier; transaction and adjudication costs in cases of dispute are lower; and there is greater familiarity amongst the creators, which works both as a deterrence mechanism against abuse, and as a motivation to allow more flexibility and willingness to share "among friends." (3) IncentivesSome limitations and exceptions correlate to the incentives of creating drag. For example, the political motivation incentive can help explain the reduced enforcement in good cause cases, the confirmation, fame and status incentive can explain the "tribute show" exception, etc. (4) AttributionUnlike many other extra-legal domains (with the notable exception of highcuisine and graffiti), ${ }^{127}$ attribution is a core element in the drag social norm system. Attribution is used also as a mechanism to reinstate ownership. Hence, even if a fellow queen has used subject matter belonging to her peer, the latter usually need not worry about dilution of her ownership, therefore, naturally, the concern of losing ownership due to exceptions and limitations is reduced.

\section{PART IV—THE PRINCIPLES OF THE DRAG DOMAIN'S SOCIAL NORMS SYSTEM}

\section{A. The Virtues and the Shortcomings of the Drag Domain's Social Norms System}

The above discussion tells us a story about the Israeli drag domain, but also about IP law and theory more generally. Although the drag domain, for the different reasons mentioned, is not regulated by IP law, instead of creators refraining from creative labor and the domain becoming a creative desert, it is a flourishing domain of intellectual creativity. This is due to it being regulated by a set of social norms that are tailored to the incentives and needs of the creators and to the unique features of the domain. Some of the orderings of the drag domain and copyright law are congruent, while others are in stark contradiction. In order to be able to consider the normative conclusions to be made of the above, we must first comprehend the virtues, as well as the shortcomings, of the drag domain's social norms system. In this chapter, I turn to analyze these.

The study of the Israeli drag domain clearly demonstrates the many advantages of social ordering systems. Three such advantages are the ability to consider the specific creators' incentives and the value they place on the different subject matter, the ability to take into account the social structure of the domain, and the domain's adjustability in the face of changes in its structure, its subject matter, technology, etc.

Consideration of incentives and subject matter's value-Communal

127 See Fauchart \& Von Hippel, supra note 3, at 193; Roundtree, supra note 3, at 973, 980. 
social ordering allows the queens to construct the social norms in a manner that reflects the incentives behind creating drag. And indeed, in the drag domain, there is direct correlation between the different norms and the incentives to create. For example, the social norms protect the drag persona (even if it is a generic concept) thus reflecting the expression of identity incentive; reduced sanctions in cases where proper attribution was given reflects the status and social standing incentive, etc. This ability is lacking in an ordering system, like IP law, that must accommodate a wide array of creators, interests, and incentives - which many times do not collide with, or even contradict each other. Another advantage of the drag domain's social norms system is that it allows the tuning of the strength of protection to the importance of the subject matter. Thus, in the drag domain, heavier sanctions are imposed on the appropriators of the more important subject matter, and a longer duration of protection is granted to it. For instance, the personas are more robustly protected than non-signature songs, and the duration of ownership in them is longer. IP law, due to the wide array of different creators, interests and incentives, cannot usually distinguish between less or more important subject matter; therefore, it imposes uniformity costs and offers a blanket protection and duration scheme.

Consideration of the social structure of the domain-Copyright law must consider many different domains of creativity, from dramatic works all the way to broadcasts. Each of these creative domains has a different social structure. If the law indeed endeavors to account for all the different domains, it must locate a common ground and refrain from responding to each of its components' unique social structures. A domain-specific ordering system, on the other hand, can. The drag domain needs to consider only itself. Hence, for example, the drag domain considers its pool of potential infringers only, rather than taking into account irrelevant ones; or, for example, the creators can rest assured that inner-communal and correlated sanctioning will work.

Adjustability-One of the major challenges IP law faces in the technological age is staying in line with a world that is constantly changing. Keeping up to date with changes in the subject matter, modes of infringement and identity of potential infringers, etc., is a very hard, if not impossible task for the legislature. Contrary to that - one of the virtues of the drag domain's social norm system is its flexibility and ability to change, to be a living instrument that can promptly adjust to a changing world. An example of that, with regards to the Israeli drag domain, is the abandonment of the geographical divide following the growth of the drag scene.

The above discussion proposed three significant advantages of the drag domain's social norm system. Most of them, ostensibly, are enjoyed by other social ordered norm systems. However, the study indicates that there are some disadvantages to the drag domain social norm system as well. 
Lack of IP Policy-The drag social norms system, like other extralegal domains' social norm systems, was crafted by the queens in light of their own personal and communal interests. The greater public interest and other policy issues were not taken into account. IP law on the other hand, allows the legislator, which is supposedly an impartial policy maker, to dictate the scope of the rights and the limitations and exceptions to the right in a manner that is supposedly serving the interests of the creators as well as the greater public interest. For example, the "fair use" exception to ownership in copyright law allows for sanction-free appropriation of copyrighted works under certain circumstances which are considered socially desirable. This, and other IP law exceptions are much broader than the exceptions that exist in the drag domain (or any other extra-legal domain). ${ }^{128}$ Another example is the propertization of ideas-unlike copyright law, the drag domain allows for ideas to become subject to a queen's ownership. It can be claimed that the propertization of ideas in the drag domain disproportionally hinders self-expression as a queen might be prevented from the use of generic concepts.

Mob Justice-In the drag domain appropriation is ostensibly rare, and when it occurs it is often settled in an amicable way. Nevertheless, in the drag domain, there are no courts, and the prosecutor is many times also the judge and the executioner. Moreover, some of the punishments, such as public shaming, are given on the spot with no prior warning. This lacks due process and may lead to cases of miscarriage of justice and false sanctioning (though, in practice, no interviewee recalled such a case).

Monopoly - The drag domain's social norms consider that certain mechanisms are required in order to prevent the possibility of appropriation a priori. However, these possibly hinder intellectual creativity. For example, physical and conceptual delimitation possibly block a queen's ability to communicate her intellectual creativity to the public. This may be viewed as an undesirable interference with the free market by a strong monopoly (or guild) that holds the key to participation in the creative domain.

\section{B. The Idea of Drag}

The above discussion illustrated the main advantages and disadvantages of the drag domain's social norm system. It seems only natural to now turn to evaluating the lessons this offers to the greater IP discourse. However, before turning to answer this question, there is yet another aspect that requires consideration. I call this aspect the idea of drag.

Drag challenges, drag contradicts, and drag questions. Every time

128 See supra Part III(B)(IV), note 125. 
drag queens are on stage that is exactly what they do. Most of the interviewees were well aware of that, though some were perhaps less explicit about this. Drag shows are meant to entertain. But this is only a part of the picture. By appearing in "women's clothes" the queens subvert the social codes that dictate what suitable attire is for both men and women. ${ }^{129}$ By performing as women, though their viewers know that they are men, they challenge society's concepts of masculinity, femininity, and gender in a broad sense. ${ }^{130}$ By being both a man and woman at the same time, they meddle with the borders of sexuality and sexual orientation. ${ }^{131}$ The drag queens challenge mainstream society's social conventions. ${ }^{132}$ Law, at least in the eyes of many of the queens, does just the opposite-it turns mainstream society's social conventions from mere social conventions into binding norms.

The inclusion or seclusion of a creative domain from the realm of law, or the opting-out of a creative domain from it, is usually not the consequence of a mere coincidence. It tells us a normative story. It tells us that the legislature or the creators chose not to include a certain domain within the law's realm. There could be, of course, different reasons for such a choice, some of which are practical but other of which are substantial. $^{133}$ A fundamental feature for some creative domains is challenging social conventions, counterculture rebellion and standing apart from mainstream society, ${ }^{134}$ and that might be the (or a) reason that they operate outside the legal realm. In their study of the stand-up comedy domain Sprigman and Oliar suggest that legal protection (or lack thereof) affects the kind of creative output produced by creators. ${ }^{135}$ My claim here is

129 Baker, supra note 11 , at 18.

130 Id.

131 Id

132 Senelick, supra note 11, at 509.

133 Fagundes contends that roller derby girls can actually protect their pseudonyms via IP laws (mainly trademark law), however, as he demonstrates, they opt not to. See supra note 3. Similarly, Perzanowski holds that tattoo artists can protect their creations using IP laws (mainly copyright law), they too chose to opt-out. See supra note 3. Loshin demonstrates that magicians view IP law as an inadequate venue for protection of their trade secrets, thus they too opt-out. See supra note 3. IP law itself chooses to exclude certain creative domain from the realm of IP protection. For example, the Israeli Patent Act (Patent Act, 5727-1967, 510 LSI 148 (1967) (Isr.)) § 7 explicitly states "no patent shall be granted for-(1) a method of therapeutic treatment on the human body; (2) new varieties of plants or animals, except microbiological organisms not derived from nature." With regards to therapeutic treatments, in the U.S. context, see Strandburg, supra note 3 (showing how a physician's attempt to enforce a patent he held for eye surgery eventually ended up in Congress's passage of Section 287(c) of the U.S. Patent Act, exempting medical professionals from patent remedies in many cases). N.b. all the above-mentioned cases are conscious decisions on behalf of the creators or the legislator to exclude a creative domain from legal protection.

134 See, e.g., Roundtree, supra note 3, at 963, 966; Fagundes, supra note 3, at 1137-38; Perzanowski, supra note 3, at 571.

135 See Sprigman \& Oliar, supra note 3. 
[Vol. 10:133

that it also possibly affects the message that the creators wish to convey via their creations. For example, let us imagine how the counterculture rebellious nature that is associated with female roller derby skaters might change if it were to become a regulated competitive sport. One can only assume that the counterculture aspects will be diminished. Same can be said about creative domains such as graffiti, tattoos and drag.

I am not suggesting that this is a decisive feature or that the advantages of juridification do not outweigh the disadvantage of impacting the massage the drag domain conveys. I merely suggest that this aspect-the impacting of the massage that a creative domain conveys - should be considered. This demonstrates how the study of the drag domain highlights yet another overlooked dimension of the nexus amongst intellectual creativity, law, and social norms, which is that law might influence the message some creative domains wish to convey, not just their subject matter and normative mechanisms. ${ }^{136}$

\section{CONCLUSION}

This article puts drag queens in the place they love most-the spotlight. It illuminates the social norm system that allows their creative domain to flourish without IP legal ordering; it delineates doctrinal and practical reasons for IP law's inability to offer the queens adequate protection; and it suggests that the idea of drag is another possible reason why IP law is not the appropriate legal apparatus to accommodate the drag domain. We should now ask ourselves what lessons the study of the drag domain holds for the wider IP discourse.

The first lesson involves the relations between creators and users. The drag domain profoundly considers these relations and takes full advantage of the fruits such relations might yield. It builds on two distinct layers- the inner social norms and the correlated-social norms, as complementary and mutually-enhancing regulating systems. This study demonstrates, for example, that viewers value original creation; that they offer greater social and economic capital to authors of original creations; and that they endeavor to see those who present them with appropriated works punished. The study also emphasizes that viewers and related services providers have a moral standing that opposes appropriation. Related services providers

136 I am aware of the possible claim that some intra-legal norms possibly challenge mainstream conventions from within the confines of law (some visual art forms, fringe theater and protest music are possible examples). However, the domains as a whole, and as such do not apparently by their nature aim to do so. Drag inherently wishes to challenge social conventions; music may wish to do so but does not necessarily wish to. Moreover, the examples of extra-legal domains such as graffiti artists that opt not to be included under IP protection possibly demonstrate that they needed to sever ties with the law in order to fulfill the idea of challenging mainstream art. $C f$. Roundtree, supra note 3, at 969 . It should be noted that Roundtree does not consider this option, however a close reading of his article regarding illegal graffiti art implicitly suggests that this is indeed a viable option. 
also have economic interests to uphold the drag norms system, such as future cooperation with the queens. This allows the queens to utilize the different users and construct the social norm system in a manner that profoundly relies on correlated-communal detection and enforcement. In the drag domain, the community - consisting of both creators and users-is the foundation of the norm system that safeguards intellectual creativity.

The second lesson engages with the message that a creative domain might wish to convey as such. The study revealed the different incentives for creation of drag, but it also illustrated that drag has an overlying ideachallenging mainstream conventions. Drag is not alone in this regard. It seems right to assert that other creative domains aspire to challenge mainstream conventions by means of creative expression. The drag domain makes us wonder not only how juridification influences the tools a creator has to protect her intellectual property, but also how it might influence the ideas a domain wishes to express by its intellectual creativity.

A third lesson we might draw from the drag domain regards the ways by which we perceive IP protection. Instead of focusing mainly on enforcement and punishment, the drag norms focus on prevention of appropriation in the first place. By considering the identity and motivations of potential appropriators and by considering the environment in which creation (and appropriation) takes place the drag norm system has devised smartly tailored prevention mechanisms that ostensibly work well. This results in fewer cases of appropriation, leading to lower adjudication costs and a (generally) peaceful creative atmosphere.

The drag domain calls on IP policy makers to think carefully before expending IP laws even further and perhaps also to rethink parts of the existing legal regime. The legislator must carefully consider whether it is wise to interfere with a creative domain —extra or intra legal—that is functioning well. Considering the ability of social norms to regulate some or all of a creative domain's IP assets, might offer innovative ways to better protect both, the creators' and the public's interest. The drag domain teaches us that there can be order without law, that users have an important role in the regulation of creative domains, that some creative domains may very well need to stay on the other side of the legal Rubicon in order to convey their message, and (following on the words of Robert Ellickson) that lawmakers who are unappreciative of the social environment's ability to regulate, are likely to create a world in which there is both more law and less order. ${ }^{137}$

137 Ellickson, supra note 39, at 286. 